\title{
Model of Regional Development in Indonesia Study on Formation of Batang Asai District and Mandiangin District at Sarolangun Regency Jambi Province
}

\author{
Fernandes Simangunsong, Imelda Hutasoit \\ Institut Pemerintahan Dalam Negeri-Kementerian Dalam Negeri (Governmental Institute of Home Affair-Ministry of Home \\ Affair), Sumedang, Indonesia \\ Email: fernandes_simangunsong@ipdn.ac.id, kisankiel@yahoo.co.id,imelda77_soit@yahoo.com
}

How to cite this paper: Simangunsong, F. and Hutasoit, I. (2018) Model of Regional Development in Indonesia Study on Formation of Batang Asai District and Mandiangin District at Sarolangun Regency Jambi Province. Open Journal of Social Sciences, 6, 69-107.

https://doi.org/10.4236/jss.2018.63006

Received: February 2, 2018

Accepted: March 13, 2018

Published: March 16, 2018

Copyright $\odot 2018$ by authors and Scientific Research Publishing Inc. This work is licensed under the Creative Commons Attribution International License (CC BY 4.0).

http://creativecommons.org/licenses/by/4.0/

cc) (7) Open Access

\begin{abstract}
This study was aimed to describe the capability level of districts and villages for formation of new ones by Sarolangun Regency Government, to describe public aspiration regarding the plan for formation of district, to describe availability of public services provided by government and quality level of the public services. This study uses application of measurement and evaluation model on capability of a region in implementation of regional autonomy. Thereby, the sample was saturated sample, by which population consists of 10 districts and 158 villages that exist in Sarolangun Regency. Conclusion of this study provides recommendation for Sarolangun Regency to plan the formation of district and village systematically and continuously with reference to result of this study showing that 10 districts and 158 villages in Sarolangun can be subdivided into 15 districts and 196 villages, respectively, with expectation that this regional reorganization and development would consider regional financial capability in order to enable the mobility of services, governance and development effectively and efficiently.
\end{abstract}

\section{Keywords}

Regional Development, Local Government, District and Village, Public Policy, Model in Indonesia

\section{Introduction}

Regional autonomy policy in Law No. 32 of 2004, as replaced by Law No. 23 of 2014, on Local Government, explicitly provides extensive autonomy to local 
government to govern and manage interests and welfare of local community. Local Government should optimize local development that is oriented to public interest. With this Law, local government and local community are more empowered and given with more responsibility to accelerate regional development rate [1].

Regulation on district, to certain degree, has experienced changes and even strengthened by Law No. 23 of 2014 on Local Government. It is understandable since control of national governance will be more effective and efficient by connecting nodes of district within perspective of development, governance and social control. Originated from article 221 clause (1), it is perceived that the spirit of formation of district is to improve governmental coordination, public services and public empowerment of both villages and sub-districts. It is furthermore elaborated in clause (3) that, in the mechanism of formation of district, participation of provincial government as agent of central government cannot be left out. This confirms that there is strong span of control connecting district government, regency government, provincial government and Ministry of Home Affairs. This is also corroborated in article 224 clause (3) stating that Governor as agent of central government has influence on the appointment of Camat (head of district) [2].

What is more spectacular is that, according to article 225 clause (1) point a, one of duties of Camat is to implement general administrative affairs, which is furthermore elaborated in article 9 clause (5) stating that general administrative affairs are under authority of president as the head of government. According to article 25 clause (1), it is explained that the meaning of general administrative duties is to develop national concept and national resilience in order to consolidate the practice of Pancasila (the Five Principles), enactment of the 1945 Constitution of the Republic of Indonesia, preservation of Bhinneka Tunggal Ika (Unity in Diversity) and maintenance of national integrity of the Unitary State of the Republic of Indonesia; development of national unity, encouragement of intra- and inter-ethnic, religious, racial, and groups relations for the stability of local, regional, and national security; management of social conflict according to law and regulations, coordination of duties between governmental institutions in province and regency/city to solve existing problems by considering principles of democracy, human rights, equality, justice, privileges, regional potential and diversity, in accordance with law and regulations, development of democratic life according to Pancasila, and implementation of all administrative affairs which are not under the authority of local government and not implemented by vertical institutions [3].

Despite that article 209 clause (2) defines district as local bureaucracy unlike Law No. 5 of 1974 which states that Camat is regional agency, Law No. 23 of 2014 provides more space in implementation of all functions of administrative management to achieve public welfare by utilizing district agencies as mandated in article 225 clause (3) that staff agency and line agency shall implement mission of district to achieve good governance, public services and public empo- 
werment [4].

In addition to affairs above, district is also delegated with authority from Regent, as stated in article 226 clause 1, 2, and 3, and also Decree of Regent, for effectiveness and efficiency of governance, public services and public empowerment. Delegation of authority from Regent to Camat followed by budgeting in National Budget (APBN) is delegation of authority in deconcentration affairs (article 225 clause 2) and in Local Budget (APBD) is delegation of authority in decentralization affairs (article 227).

Before enactment of this new law, district was assigned more to implement facilitating and coordination duties. Now, however, district has been assigned more to develop and supervise villages/sub-districts as mandated in article 225 clause (1) point $\mathrm{g}$. These are furthermore added by enactment of Law No. 6 of 2014 on Village that, in addition to manage internal potentials, district shall also manage villages/sub-districts with every dimensions in them. Therefore, it is necessary to have good management skills of planning, organizing, implementing, and controlling.

In administration of district government, Law No. 23 of 2014 also provides space for innovation. Innovation can be in form of ways to govern effectively and efficiently, ways to provide good public services, and ways to empower public effectively and efficiently. The spaces are provided in terms of to increase efficiency, to improve effectiveness, to improve service quality, to avoid conflict of interests, to be public-oriented, to be transparent, to comply with appropriateness, to have unselfish accountable result (article 387). In fact, article 389states that in case of the implementation of innovation under the policy of local government fails to meet its objective, civil servant cannot be convicted.

In Government Regulation No. 19 of 2008 on District, it is clearly stated that formation of new district can be dividing of one district into two or more new districts; and/or integration of villages and/or sub-districts from several districts. In this Government Regulation, it is also stated that formation of district requires several requirements, namely: administrative, technical, and territorial physical [5].

According to Law No. 32 of 2004 on Local Government, and its derivative Government Regulation No. 19 of 2008 on District, it is stated that criteria for formation of district are:

1) Administrative requirements to be met are:

a) Minimum age of administration by 5 (five) years;

b) Minimum age of village and/or sub-district administration for formation of district is 5 (five) years;

c) Decision of Badan Permusyawaratan Desa (BPD) (Village Consultative Council) or other name for Village, Communication Forum of Sub-district or other name for Sub-district, in whole district region, both in proposed new district and parent district, regarding agreement for formation of new district;

d) Decision of Village Chief or other name for Village, Head of Sub-district or other name for Sub-district, in whole district region, both in proposed new dis- 
trict and parent district, regarding agreement for formation of new district;

e) Recommendation from Governor.

2) Territorial physical requirements to be met are:

a) Territorial coverage, as mentioned in Article 5, for regency should at least consist of 10 villages/Sub-districts, and for city should at least consist of 5 villages/Sub-districts.

b) Location of proposed capital, as mentioned in Article 5, should consider aspects of spatial, availability of facility, accessibility, geographical condition and location, demography, socio-economic, socio-political, and sociocultural.

c) Administrative facilities and infrastructures, as mentioned in Article 5, consist of buildings and lands for office of Camat to provide public services.

3) Technical requirements to be met are:

a) population size;

b) area size;

c) span of control in providing administrative services;

d) economic activities;

e) Availability of facilities and infrastructures [6].

Law No. 32 of 2004 has been replaced by law No. 23 of 2014 on Local Government, and Central Government is also preparing Government Regulation in Lieu of GR No. 19 of 2008 on District which is currently under discussion and still in form of Rancangan Peraturan Pemerintah (RPP) (Draft Government Regulation (DGR)). According to Law No. 23 of 2014 Article 222 and Draft Government Regulation in Lieu of GR No. 19 of 2008, it is stated that:

Central government and local government shall reorganize districts, comprising:

1) establishment; and

2) elimination and merging.

Regency/city government establishes district in order to improve governmental coordination, public services, and public empowerment of Village/Sub-district, and it is established by regional regulation of regency/city.

Formation of district can be:

1) Dividing of 1 (one) district into 2 (two) or more districts; and/or

2) Merging of part of district from adjacent districts within a regency/city into new district.

Formation of district should meet basic, technical, and administrative requirements.

1) Basic requirements include:

a) Minimum population size;

b) Minimum area size;

c) Minimum number of villages/sub-districts under coverage; and

d) Minimum age of district.

2) Technical requirements include:

a) Regional financial capability;

b) Administrative facilities and infrastructures; and 
c) Other technical requirements as regulated in law and regulations.

3) Administrative requirements include:

a) Village consensus and/or decision of communication forum of Sub-district or any other name in parent district; and

b) Village consensus and/or decision of communication forum of Sub-district or any other name in proposed formed district [7].

This study uses elaboration of three variables (Decree of Minister of Home Affairs No. 4/200) and GR No. 19 of 2008 on District, and main variable in Law No. 23 of 2014, and also measurement of potential is carried out by simulation of GR No. 129 of 2000 and its replacing Government Regulation, GR No. 78 of 2008 on Requirement for Formation and Criteria for Establishment, Elimination and Merging of Regions, by considering other variables that may support the requirement for formation of district, such as demography, orbitasi (distance from administrative capital), education, health, religion, sport facilities, transportation, communication, public lighting, politics, public security and order, agriculture, fishery, livestock, mining, employment, sociocultural, social economy, social condition and administrative aspect [8].

\section{Problem Statement}

Problem statement for this study on formation of district and village in Sarolangun Regency Jambi Province can be formulated as follows:

1) How is capability level of districts and villages in Sarolangun Regency in administration of government, development and providing public services?

2) How is description on public aspiration regarding the plan for formation of district and village in Sarolangun Regency?

3) How is availability of public services provided by government in Sarolangun Government?

4) How is quality level of public services provided by government in Sarolangun Government?

\section{Theoretical Framework}

Study on Formation of District in Sarolangun Regency is divided in stages according to theoretical framework as follows:

\subsection{Formation and Reordering at the Level of Village/Sub-District (Formation of Village/Sub-District)}

The purpose of regional autonomy policy as mentioned in Law No. 32 of 2004 is improvement for better public service and welfare, encouragement of democratic life, justice, and equality, and also preservation of harmony relationship between central and local government and inter local governments for integrity of the Unitary State of the Republic of Indonesia. In line with this, regional autonomy is placed entirely for regency/city, and delegation of authority of regional autonomy to regency/city is based on extensive, real and responsible decentra- 
lization principle. The achievement of this purpose would be determined by the capability level of villages/Sub-districts as the smallest unit of government which also the nearest to community that provide public services, implement the development and improvement of democracy.

Law No. 32 of 2004 Article 227 clause (1) states that Sub-district can be formed in district region by local regulation with reference to Government Regulation. GR No. 73 of 2004 on Sub-district furthermore elaborates that formation of new Sub-district should consider population size, area size, sociocultural, potential of the Sub-district, and administrative facilities and infrastructures. This regulation provides spaces for formation of new Sub-district through subdivision of Sub-district as long as it is aspired by the public and it shall achieve the purpose of effective administration of government, public services, development and democratization at the smallest unit of government. For this purpose, it is required to measure and evaluate the potential of the Sub-district as the basis of whether it is adequate or not for formation of new district.

Result of the measurement considers main factor, consisting of accumulation of population size and total number of head of family, and supporting factors comprising particular total score of potential capability level which serve as basis for evaluation of whether a Sub-district is adequate or not for formation. Evaluation of potential capability level for formation of Sub-district is evaluation of potential of the parent Sub-district and the plan for formation of Sub-district. Result of evaluation can be categorized into 3 (three) levels, qualified/ proper, qualified with condition/fairly proper and unqualified/improper. Result of evaluation serves as recommendation for policy as follows:

1) If proposed parent Sub-district and proposed formed Sub-district for formation both meet the requirements according to main factor and are qualified/proper according to supporting factor, the chosen action would be recommended for dividing of Sub-district or establishment of new Sub-district;

2) If proposed parent Sub-district and proposed formed Sub-district for formation meet the requirements according to main factor and both qualified with condition/fairly proper or unqualified/improper according to supporting factor, the chosen action would be recommended for dividing of Sub-district or for establishment of new Sub-district, followed by development of potential into qualified/proper within certain period of time;

3) If any of proposed parent Sub-district and proposed formed Sub-district fail to meet the requirements according to main factor and is qualified/proper or is qualified with condition/fairly proper or unqualified/is improper according to supporting factor, it is not recommended for dividing of Sub-district or establishment of new Sub-district.

\subsection{Development and Reordering at the Level of District (Formation of District)}

The corrective purpose of regional autonomy as mentioned in Law No. 22 of 
1999 is improvement of public service and welfare, encouragement of democratic life, justice, and equality, and also preservation of harmony relationship between central and local government and inter local governments for integrity of the Unitary State of the Republic of Indonesia. Whereas, according to Law No. 32 of 2004 and Law No. 23 of 2014, the purpose is aimed to accelerate the realization of public welfare through improvement of public service, public empowerment and public participation. In line with this, regional autonomy is placed entirely for regency/city, and delegation of authority of regional autonomy to regency/city is based on extensive, real and responsible decentralization principle.

The achievement of this purpose would be determined by the capability level of districts as the one of governmental units nearest to community that provide public services, implement the development and improvement of democracy. Formation of district is aimed to create effectiveness in administration of government, public service, development and democratization. For this purpose, it is required to measure and evaluate the potential of the district as the basis of whether it is adequate or not for formation of new district [9].

Potentials which are considered reliable for formation of district and measurable and evaluable in 21 (twenty one) variables are demography, orbitasi (distance from administrative capital), education, health, religion, sport facilities, transportation, communication, public lighting, politics, public security and order, agriculture, fishery, livestock, mining, employment, sociocultural, social economy, social condition and administrative aspect. Result of evaluation is particular total score of potential capability level which serve as basis for evaluation of whether a district is adequate or not for formation. Evaluation of potential capability level for formation of district is evaluation of potential of the parent district and the plan for formation of district. Result of evaluation can be categorized into 3 (three) levels, namely high, adequate, and low. Result of evaluation serves as recommendation for policy as follows:

If parent district and formed district have high potential, action to be taken is to recommend the formation of district;

1) If parent district and formed district have adequate potential, action to be taken is to do formation of district followed by development of potential within certain period of time such as minimum 3 or 5 years for evaluation. If they fail to meet the requirements within the period of time, it is recommended to be re-merged with parent district.

2) If both or either of governmental units have/has low potential, action to be taken is to postpone the formation of district. For districts of low potential, it is recommended to implement improvement of potential into adequate category, and after having adequate potential, development of potential is held to be proper for formation of district. However, if potential of the district is extremely low, it is not qualified for formation of district.

In addition, establishment of district should also consider public aspiration. If result of survey indicates that more than $50 \%$ of people demand for establish- 
ment of new district, then it is qualified for formation. Likewise, if result of survey on public services indicates that more than $50 \%$ respond that the public services are poor or low quality, then it is qualified for formation. Below (Figure 1) is shown the picture of theoretical framework.

\section{Research Method}

Operational definition of variables in the study of Formation of District in Sarolangun Regency is limited according to developmental space and regional reordering which format is elaborated in GR No. 19 of 2008 on District, GR No. 78 of 2007 on Procedure for Establishment, Elimination and Merging of Regions and Law No. 23 of 2014 on Local Government and also DGR in lieu of GR No. 19 of 2008. Seeing the plan for Formation of District at Sarolangun Regency which begins from reordering and development at the level of Village/Sub-District (formation of Village/Sub-district), there are 19 factors made as variable of research as follows (Table 1):

Data processing techniques in this study of formation of district in Sarolangun Regency are divided into three stages of regional development and reordering, namely:

1) Qualitative data is analyzed by content and depth approach, translating a phenomenon on 19 (nineteen) variables. How to accommodate the qualitative analysis is by stimulating various inclinations of qualitative responses from respondents on those phenomena.

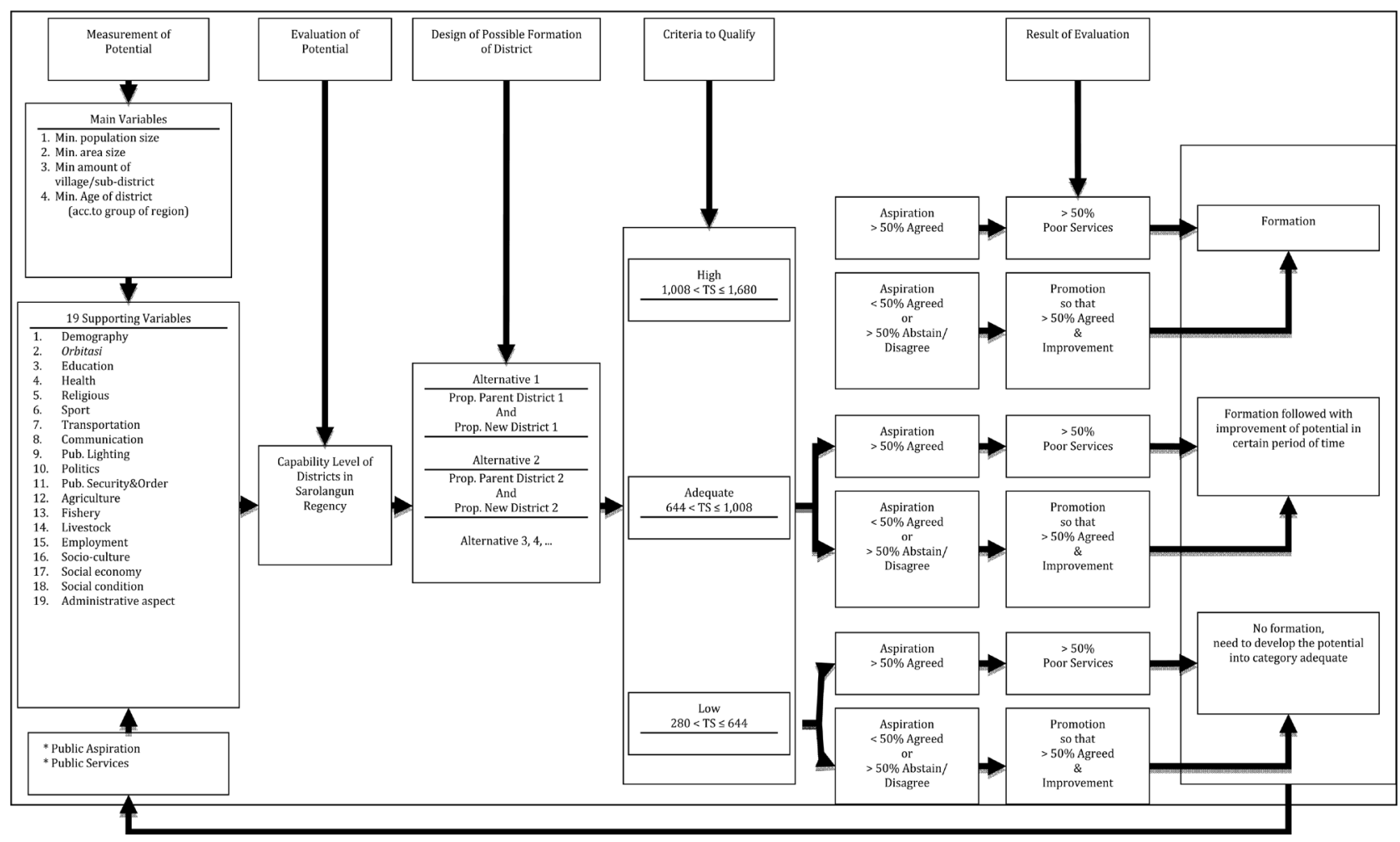

Figure 1. Theoretical framework for formation of Sarolangun District. 
Table 1. Formation of district.

\section{No Factors and Indicators}

1. Demography
1. Population Size
2. Number of Household
3. Area Size.
4. Number of Community Unit
5. Number of Head of Family
6. Population Density

2. Orbitasi

1. Traveling Distance from Village/Sub-district to District

2. Traveling Time from Village/Sub-district to District

\section{Education}
1. Number of educational facilities
2. Illiteracy rate
3. Dropout rate
4. General education graduation rate
5. Index of vocational institutions

\section{Health}
1. Number of health facilities, medics, infant and child mortality rate
2. Baby and child immunization participation rate
3. Child malnutrition index
4. Ratio of family toilet to household
5. Ratio of pre-prosperous family to population
6. Ratio of drinking water facilities to population
7. Index of house condition

5. Religion

1. Number of religious facilities

6. Sport Facilities

1. Index comparison between sport facilities and population size

7. Transportation

1. Index of transportation facilities

8. Communication

1. Index of communication facilities

9. Public Lighting

1. Number of electricity consumers

2. Number of other public lighting

10. Political Awareness
1. Number of voting rights
2. Number of voters
3. Number of Political Parties 


\section{Continued}

4. Number of NGOs/other society organizations

\section{Public Security and Order}

1. Number of security facilities

2. Number of security personnel

\section{Agriculture}

1. Index comparison of area size, yield, and ownership of plantation of non-rice crops, vegetables, fruits and rice fields.

2. Number of groups of farmers, irrigation managers, and fice field and plantation facilities.

13. Fishery

1. Aquacultural area size

2. Fishery yield and ownership

\section{Livestock}

1. Large and mid-sized livestock

2. Poultry

15. Employment

1. Number employed population

2. Number of job-seeking population

3. Number of unemployed population

4. Number of large, medium, and small enterprises

5. Number of agricultural companies

16. Socio-culture

1. Number of art facilities

2. Number of orphanages

3. Number of tourism facilities

17. Social Economy
1. Shopping facilities
2. Banking Institution
3. Non-Bank Financial Institution

18. Social Condition

1. Number of people with physical disabilities

2. Number of troubled people who become burden of government

\section{Administrative Aspect}
1. Land and Property Tax
2. Village Locally Generated Revenue
3. Other Sub-district Revenue
4. Number of Sub-district Apparatus, BPD and KPD
5. Decision of Sub-district
6. Regulation of Sub-district 
2) By list of open-end structured questions, complemented with compilation of in-depth interviews and field observation, the variables are compiled into structured file. However, some of the qualitative data are renovated into quantitative data through non-parametric process. Quantitative data is categorized, classified and processed as basis for measurement and analysis to provide clarity and valuation on strength and weakness of the variables.

3) Category of valuation on monograph of Village/Sub-district is based on certain scale and defined according to very high, high, adequate, low and very low classifications based on representative particular total score. Each category of valuation serves as basis for action taken whether or not to implement the formation of district and exploitation of its potential.

Evaluation method is determined by distribution method using mean to account for data distribution. Score calculation with this method is adjusted by skewness and kurtosis of data distribution curve. Each sub-indicator has the lowest score of 1 and highest score of 6 . For scoring, the steps are:

1) Calculate mean, standard deviation, and coefficient of kurtosis/skewness.

2) Calculate limit 2 (value $2 \times$ kurtosis/skewness $x$ standard deviation), and limit 1 (value $1 \times$ kurtosis $\mathrm{x}$ standard deviation) and;

3) Determine index class for scoring:

a) If indicator value $>$ mean + limit 2 , the score is 6

b) If mean + limit $2 \leq$ indicator value $<$ mean + limit 1 , the score is 5 ;

c) If mean + limit $1 \leq$ indicator value $<$ mean, the score is 4 ;

d) If mean $\leq$ indicator value $<$ mean - limit 1 , the score is 3 ;

e) If mean - limit $1 \leq$ indicator value $<$ mean - limit 2 , the score is 2 ;

f) If indicator value $\leq$ mean - limit 2 , the score is 1 ;

Assumption used in valuing is every variable or criteria has distinctive value according to its role and urgency in the administration of government, development and social. Value for basic services such as health and education are 11, for communication facilities, transportation, social economy and public lighting are 7, for demography, socio-culture, politics, orbitasi, dan agriculture are 5, for employment, administrative aspect, religious facilities, sport facilities, public security and order, livestock and fishery are 3 , for social condition is 2 , and for forestry and mining are 1. Minimum passing score is accumulated total score of sub-indicators in each variablelgroup of criteria multiplied by score above average for each variable or group of criteria multiplied by value for each group of indicators. Calculation of minimum and maximum total score of each and every variable can be seen in Table as follows (Table 2).

A district is qualified for formation if reaching minimum score of 1680 or high potential, minimum passing score is total of sub-indicators in each variable/group of criteria multiplied by score above average for each variable or group of criteria multiplied by value for each group of indicators. Assumption used is score above average for each variable is 3.6 between interval 1 to 6 . For more elaboration, see Table 3. 
Table 2. Maximum and minimum score of variables.

\begin{tabular}{|c|c|c|c|c|c|c|c|}
\hline \multirow[b]{2}{*}{ No } & \multirow[b]{2}{*}{ VARIABLE } & \multirow{2}{*}{$\begin{array}{l}\text { NUMBER OF } \\
\text { INDICATOR }\end{array}$} & \multirow[b]{2}{*}{ VALUE } & \multirow{2}{*}{$\begin{array}{l}\text { MINIMUM } \\
\text { SCORE }\end{array}$} & \multirow{2}{*}{$\begin{array}{l}\text { MAXIMUM } \\
\text { SCORE }\end{array}$} & \multicolumn{2}{|c|}{ TOTAL TOTAL } \\
\hline & & & & & & $\begin{array}{c}\text { MIN } \\
\text { SCORE }\end{array}$ & $\begin{array}{c}\text { MAX } \\
\text { SCORE }\end{array}$ \\
\hline 1 & DEMOGRAPHY & 3 & 5 & 1 & 6 & 15 & 90 \\
\hline 2 & ORBITASI & 2 & 5 & 1 & 6 & 10 & 60 \\
\hline 3 & EDUCATION & 4 & 11 & 1 & 6 & 44 & 264 \\
\hline 4 & HEALTH & 5 & 11 & 1 & 6 & 55 & 330 \\
\hline 5 & RELIGIOUS & 1 & 3 & 1 & 6 & 3 & 18 \\
\hline 6 & SPORT & 1 & 3 & 1 & 6 & 3 & 18 \\
\hline 7 & TRANSPORTATION & 1 & 7 & 1 & 6 & 7 & 42 \\
\hline 8 & COMMUNICATION & 1 & 7 & 1 & 6 & 7 & 42 \\
\hline 9 & PUBLIC LIGHTING & 2 & 7 & 1 & 6 & 14 & 84 \\
\hline 10 & $\begin{array}{l}\text { POLITICAL } \\
\text { AWARENESS }\end{array}$ & 3 & 5 & 1 & 6 & 15 & 90 \\
\hline 11 & $\begin{array}{c}\text { PUBLIC SECURITY } \\
\text { AND ORDER }\end{array}$ & 2 & 3 & 1 & 6 & 6 & 36 \\
\hline 12 & AGRICULTURE & 2 & 5 & 1 & 6 & 10 & 60 \\
\hline 13 & FISHERY & 2 & 3 & 1 & 6 & 6 & 36 \\
\hline 14 & LIVESTOCK & 2 & 3 & 1 & 6 & 6 & 36 \\
\hline 15 & EMPLOYMENT & 3 & 3 & 1 & 6 & 9 & 54 \\
\hline 16 & SOCIO-CULTURE & 3 & 5 & 1 & 6 & 15 & 90 \\
\hline 17 & SOCIAL ECONOMY & 3 & 7 & 1 & 6 & 21 & 126 \\
\hline 18 & SOCIAL CONDITION & 2 & 2 & 1 & 6 & 4 & 24 \\
\hline 19 & $\begin{array}{c}\text { ADMINISTRATIVE } \\
\text { ASPECT }\end{array}$ & 6 & 5 & 1 & 6 & 30 & 180 \\
\hline \multicolumn{6}{|c|}{ TOTAL } & 280 & 1.680 \\
\hline
\end{tabular}

According to table above, it is seen that score above average is 1008. It means that a district is declared to be qualified for establishment of new district if the score from measurement is equal to or greater than 1008. On that basis, category for evaluation on potential of district in administration of government, development and social can be defined as shown in Table 4 .

\section{Result}

Based on result of field study, several things can be described as follows:

\subsection{Regional Potential of All Districts and Villages in Sarolangun Regency}

Result of evaluation and measurement on potential of districts and villages in each district in Sarolangun Regency can be seen as follows (Table 5):

1) Potential of Districts in Sarolangun Regency

Based on table above, there are 5 districts in category of proper for formation, 
Table 3. Score above average with score 3.6 with category of adequate potential.

\begin{tabular}{|c|c|c|c|c|c|}
\hline No & VARIABLE & $\begin{array}{l}\text { NUMBER OF } \\
\text { INDICATOR }\end{array}$ & VALUE & $\begin{array}{c}\text { SCORE } \\
\text { ABOVEAVERAGE }\end{array}$ & $\begin{array}{l}\text { TOTAL } \\
\text { SCORE }\end{array}$ \\
\hline 1 & DEMOGRAPHY & 3 & 5 & 3.6 & 54 \\
\hline 2 & ORBITASI & 2 & 5 & 3.6 & 36 \\
\hline 3 & EDUCATION & 4 & 11 & 3.6 & 158 \\
\hline 4 & HEALTH & 5 & 11 & 3.6 & 198 \\
\hline 5 & RELIGIOUS & 1 & 3 & 3.6 & 11 \\
\hline 6 & SPORT & 1 & 3 & 3.6 & 11 \\
\hline 7 & TRANSPORTATION & 1 & 7 & 3.6 & 25 \\
\hline 8 & COMMUNICATION & 1 & 7 & 3.6 & 25 \\
\hline 9 & PUBLIC LIGHTING & 2 & 7 & 3.6 & 50 \\
\hline 10 & POLITICAL AWARENESS & 3 & 5 & 3.6 & 54 \\
\hline 11 & PUBLIC SECURITY AND ORDER & 2 & 3 & 3.6 & 22 \\
\hline 12 & AGRICULTURE & 2 & 5 & 3.6 & 36 \\
\hline 13 & FISHERY & 2 & 3 & 3.6 & 22 \\
\hline 14 & LIVESTOCK & 2 & 3 & 3.6 & 22 \\
\hline 15 & EMPLOYMENT & 3 & 3 & 3.6 & 32 \\
\hline 16 & SOCIO-CULTURE & 3 & 5 & 3.6 & 54 \\
\hline 17 & SOCIAL ECONOMY & 3 & 7 & 3.6 & 76 \\
\hline 18 & SOCIAL CONDITION & 2 & 2 & 3.6 & 14 \\
\hline 19 & ADMINISTRATIVE ASPECT & 6 & 5 & 3.6 & 108 \\
\hline \multicolumn{5}{|c|}{ TOTAL } & 1008 \\
\hline
\end{tabular}

Table 4. Category of action taken.

\begin{tabular}{cccc}
\hline NO & VARIABLE & $\begin{array}{c}\text { INTERVAL } \\
\text { OFTOTALSCORE }\end{array}$ & VALUE \\
\hline 1 & High Potential & $1008 \leq \mathrm{TS}<1680$ & $\begin{array}{c}\text { Qualified for formation } \\
\text { Qualified for formation followed by } \\
\text { improvement of potential within certain } \\
\text { period of time }\end{array}$ \\
3 & Adequate Potential & $644 \leq \mathrm{TS}<1008$ & \begin{tabular}{c} 
Unqualified for formation \\
\hline
\end{tabular} \\
\hline
\end{tabular}

namely Batang Asai, Pelawan, Singkut, Sarolangun and Mandiangin. As for category of fairly proper for formation, there are 5 districts, namely Limun, Cernin Nan Gedang, Batin VIII, Pauh and Air Hitam. District with minimum score is Pauh by 807. District with maximum score is Mandiangin by 1171. Difference of regional potential of district between the highest and the lowest score is 364 or $45 \%$ of the lowest regional potential of district. For more complete comparison of potential per district between the highest and the lowest potential, the result can be shown as follows (Table 6). 
Table 5. Recapitulation of potential of districts in Sarolangun regency.

\begin{tabular}{|c|c|c|c|c|c|}
\hline NO & REGENCY & DISTRICT & $\begin{array}{l}\text { TOTAL } \\
\text { SCORE }\end{array}$ & SCORE INTERVAL & CATEGORY \\
\hline 1 & \multirow{10}{*}{ Sarolangun } & Batang Asai & 1012 & $1008 \leq \mathrm{TS}<1680$ & Proper \\
\hline 2 & & Limun & 980 & $644 \leq \mathrm{TS}<1008$ & Fairly Proper \\
\hline 3 & & Cermin Nan Gedang & 832 & $644 \leq \mathrm{TS}<1008$ & Fairly Proper \\
\hline 4 & & Pelawan & 1116 & $1008 \leq \mathrm{TS}<1680$ & Proper \\
\hline 5 & & Singkut & 1032 & $1008 \leq \mathrm{TS}<1680$ & Proper \\
\hline 6 & & Sarolangun & 1072 & $1008 \leq \mathrm{TS}<1680$ & Proper \\
\hline 7 & & Batin VIII & 896 & $644 \leq \mathrm{TS}<1008$ & Fairly Proper \\
\hline 8 & & Pauh & 807 & $644 \leq \mathrm{TS}<1008$ & Fairly Proper \\
\hline 9 & & Air Hitam & 921 & $644 \leq \mathrm{TS}<1008$ & Fairly Proper \\
\hline \multirow[t]{5}{*}{10} & & Mandiangin & 1171 & $1008 \leq \mathrm{TS}<1680$ & Proper \\
\hline & \multicolumn{2}{|c|}{ TOTAL } & 9839 & & \\
\hline & \multicolumn{2}{|c|}{ AVERAGE } & 984 & & \\
\hline & \multicolumn{2}{|c|}{ TOTAL MINIMUM SCORE } & 807 & & \\
\hline & \multicolumn{2}{|c|}{ TOTAL MAXIMUM SCORE } & 1171 & & \\
\hline
\end{tabular}

Source: Data Processing, 2017.

Table 6. Comparison of potential of districts in Sarolangun regency.

\begin{tabular}{|c|c|c|c|c|c|c|}
\hline No & REGENCY & DISTRICT & $\begin{array}{l}\text { TOTAL } \\
\text { SCORE }\end{array}$ & DIFFERENCE & PERCENTAGE & $\begin{array}{c}\text { NOMINATED } \\
\text { DISTRICT }\end{array}$ \\
\hline 1 & & Batang Asai & 1012 & 205 & 25 & 2 \\
\hline 2 & & Limun & 980 & 173 & 21 & 1 \\
\hline 3 & & $\begin{array}{c}\text { Cermin Nan } \\
\text { Gedang }\end{array}$ & 832 & 25 & 3 & 1 \\
\hline 4 & & Pelawan & 1116 & 309 & 38 & 2 \\
\hline 5 & Sarolangun & Singkut & 1032 & 225 & 28 & 2 \\
\hline 6 & & Sarolangun & 1072 & 265 & 33 & 2 \\
\hline 7 & & Batin VIII & 896 & 89 & 11 & 1 \\
\hline 8 & & Pauh & 807 & 0 & 0 & 1 \\
\hline 9 & & Air Hitam & 921 & 114 & 14 & 1 \\
\hline 10 & & Mandiangin & 1171 & 364 & 45 & 2 \\
\hline \multicolumn{6}{|c|}{ Total Formation } & 15 \\
\hline
\end{tabular}

Source: Data Processing, 2017.

District with potential of equal to or greater than the lowest regional potential of district by $30 \%$ can be said as having great potential for formation. Based on table above, the result shows that from 10 (ten) districts available, there are 15 (fifteen) nominated districts if formation to be implemented. Qualified districts with better potential for formation are Batang Asai, Pelawan, Singkut, Sarolan- 
gun and Mandiangin. With 5 (five) districts qualified for formation, each into parent district and newly formed district, the number of district will be from 10 into 15 districts.

\section{2) Potential of Villages in each District in Sarolangun Regency}

Based on result of analysis above (Table 7), by the mapping of villages in Sarolangun Regency, there are 38 (thirty-eight) villages in the category of proper for formation and 120 (one hundred and twenty) villages in the category of fairly proper for formation. Village with minimum score is Sungai Bemban village, Batang Asai district, by 835. And village with maximum score is Payo Lebar village, Singkut district, by 1140. Difference of regional potential of villages in Sarolangun Regency between the highest and the lowest score is 305 or $37 \%$ of the lowest regional potential of village. For more complete comparison of potential per village in Sarolangun Regency between the highest and the lowest potential, the result can be shown as follows (Table 8).

Villages in Sarolangun Regency with potential of equal to or greater than the lowest regional potential of village by $30 \%$ can be said as having great potential for formation. Based on table above, the result shows that from 158 (one hundred and fifty-eight) villages in Sarolangun Regency, there are 196 (one hundred and ninety-six) nominated villages can be formed if formation to be implemented. Qualified villages with better potential for formation are shown in table below.

\subsection{Formation of Batang Asai District and Mandiangin District}

Based on analysis result of evaluation and measurement on potential of districts and villages in each district in Sarolangun Regency, Sarolangun Regency Government shall implement formation of 2 (two) districts, namely Batang Asai and Mandingin, because only those 2 (two) districts are qualified in terms of having minimum 10 villages/sub-districts. Below is the explanation:

1) Formation of Batang Asai District and Mandiangin District based on Aspect of Regional Potential

\section{a) Formation of Batang Asai District}

Potential of villages in Batang Asai district, Sarolangun Regency based on result of study on regional potential of Batang Asai district, Sarolangun Regency by scoring on 19 (nineteen) variables (attached), with category of proper, fairly proper or improper for formation are shown in table as follows (Table 9).

Based on result of analysis above, by the mapping of villages in Batang Asai District, Sarolangun Regency, there are 6 (six) villages in the category of proper for formation and 17 (seventeen) villages in the category of fairly proper for formation. In terms of formation of Batang Asai District, there are 3 (three) alternatives of formation of Batang Asai District:

\section{1) Alternative 1 of Formation of Batang Asai District}

Mapping of villages in Batang Asai District in alternative 1 is the formed district with nominated villages of Batin Pengambang, Tambak Ratu, Muara Air 
Table 7. Potential of villages in whole Sarolangun regency.

\begin{tabular}{|c|c|c|c|c|c|}
\hline NO & DISTRICT & VILLAGE & $\begin{array}{l}\text { TOTAL } \\
\text { SCORE }\end{array}$ & SCORE INTERVAL & CATEGORY \\
\hline 1 & & Pekan Gedang & 1041 & $1008 \leq$ TS $<1680$ & Proper \\
\hline 2 & & Bukit Kalimau Ulu & 868 & $644 \leq \mathrm{TS}<1008$ & Fairly Proper \\
\hline 3 & & Raden Anom & 1011 & $1008 \leq \mathrm{TS}<1680$ & Proper \\
\hline 4 & & Pulau Salak Baru & 857 & $644 \leq \mathrm{TS}<1008$ & Fairly Proper \\
\hline 5 & & Rantau Panjang & 947 & $644 \leq \mathrm{TS}<1008$ & Fairly Proper \\
\hline 6 & & Padang Jering & 843 & $644 \leq \mathrm{TS}<1008$ & Fairly Proper \\
\hline 7 & & Kasiro & 939 & $644 \leq \mathrm{TS}<1008$ & Fairly Proper \\
\hline 8 & & Kasiro Ilir & 847 & $644 \leq \mathrm{TS}<1008$ & Fairly Proper \\
\hline 9 & & Datuk Nan Duo & 941 & $644 \leq \mathrm{TS}<1008$ & Fairly Proper \\
\hline 10 & & Sungai Baung & 901 & $644 \leq \mathrm{TS}<1008$ & Fairly Proper \\
\hline 11 & & Sungai Bemban & 835 & $644 \leq \mathrm{TS}<1008$ & Fairly Proper \\
\hline 12 & Batang Asai & Lubuk Bangkar & 859 & $644 \leq \mathrm{TS}<1008$ & Fairly Proper \\
\hline 13 & & Muara Pemuat & 862 & $644 \leq \mathrm{TS}<1008$ & Fairly Proper \\
\hline 14 & & Muara Cuban & 872 & $644 \leq \mathrm{TS}<1008$ & Fairly Proper \\
\hline 15 & & Batu Empang & 1009 & $1008 \leq \mathrm{TS}<1680$ & Proper \\
\hline 16 & & Bathin Pengambang & 1014 & $1008 \leq \mathrm{TS}<1680$ & Proper \\
\hline 17 & & Tambak Ratu & 1028 & $1008 \leq$ TS $<1680$ & Proper \\
\hline 18 & & Muara Air Dua & 1018 & $1008 \leq \mathrm{TS}<1680$ & Proper \\
\hline 19 & & Simpang Narso & 877 & $644 \leq \mathrm{TS}<1008$ & Fairly Proper \\
\hline 20 & & Sungai Keradak & 893 & $644 \leq \mathrm{TS}<1008$ & Fairly Proper \\
\hline 21 & & Bukit Sulah & 907 & $644 \leq \mathrm{TS}<1008$ & Fairly Proper \\
\hline 22 & & Paniban Baru & 883 & $644 \leq \mathrm{TS}<1008$ & Fairly Proper \\
\hline 23 & & Bukit Berantai & 884 & $644 \leq \mathrm{TS}<1008$ & Fairly Proper \\
\hline 1 & & Mersip & 964 & $644 \leq \mathrm{TS}<1008$ & Fairly Proper \\
\hline 2 & & Berkun & 918 & $644 \leq \mathrm{TS}<1008$ & Fairly Proper \\
\hline 3 & & Lubuk Bedorong & 890 & $644 \leq \mathrm{TS}<1008$ & Fairly Proper \\
\hline 4 & & Meribung & 862 & $644 \leq \mathrm{TS}<1008$ & Fairly Proper \\
\hline 5 & & Napal Melintang & 898 & $644 \leq \mathrm{TS}<1008$ & Fairly Proper \\
\hline 6 & & Panca Karya & 947 & $644 \leq \mathrm{TS}<1008$ & Fairly Proper \\
\hline 7 & Limun & Demang & 932 & $644 \leq \mathrm{TS}<1008$ & Fairly Proper \\
\hline 8 & & Ranggo & 923 & $644 \leq \mathrm{TS}<1008$ & Fairly Proper \\
\hline 9 & & Muara Mensao & 990 & $644 \leq \mathrm{TS}<1008$ & Fairly Proper \\
\hline 10 & & Tanjung Raden & 889 & $644 \leq \mathrm{TS}<1008$ & Fairly Proper \\
\hline 11 & & Temenggung & 915 & $644 \leq \mathrm{TS}<1008$ & Fairly Proper \\
\hline 12 & & Mounti & 932 & $644 \leq \mathrm{TS}<1008$ & Fairly Proper \\
\hline 13 & & Pulau Pandan & 974 & $644 \leq \mathrm{TS}<1008$ & Fairly Proper \\
\hline
\end{tabular}




\section{Continued}

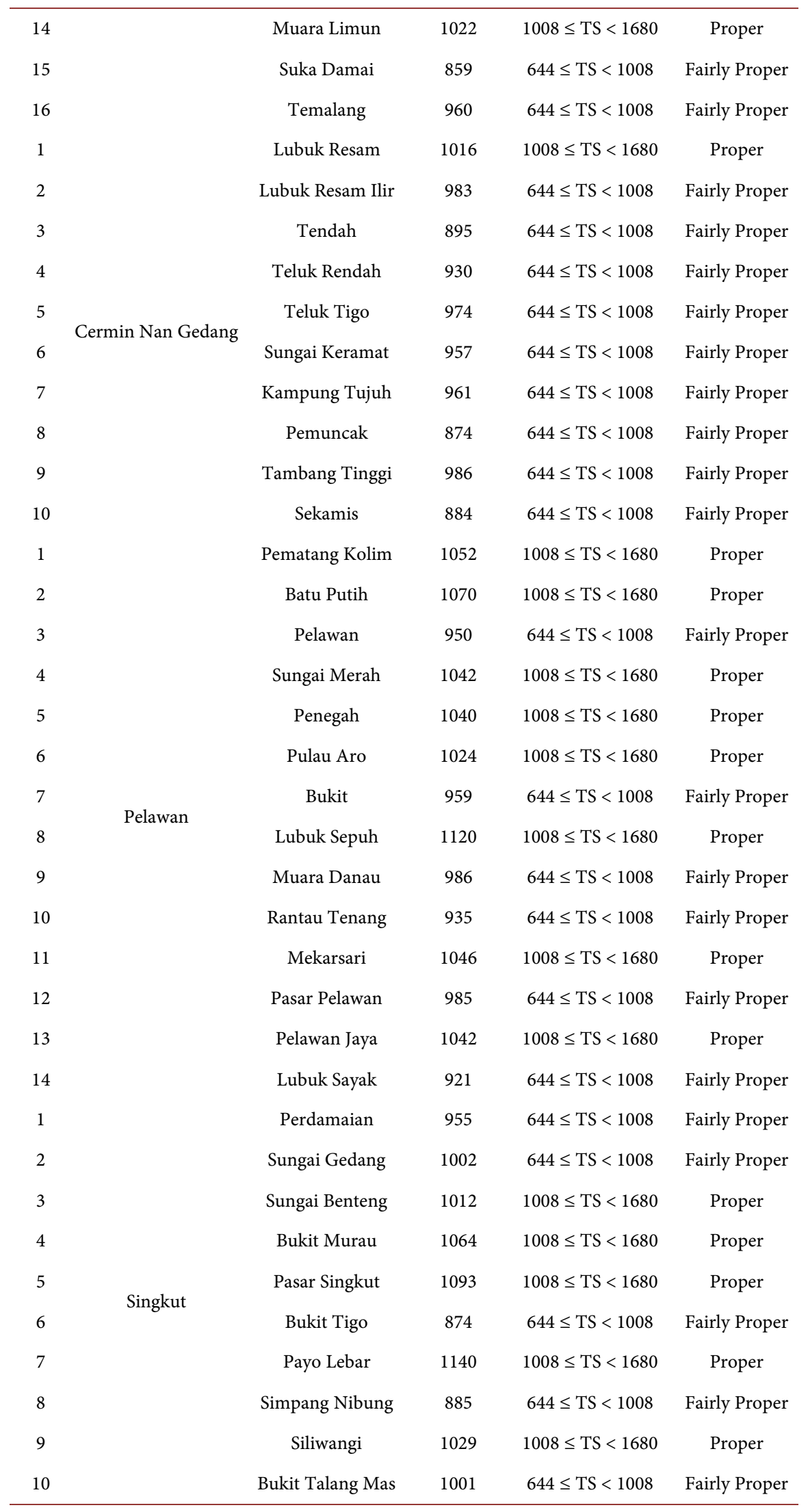




\section{Continued}

\begin{tabular}{|c|c|c|c|c|c|}
\hline 11 & & Bukit Bumi Raya & 1028 & $1008 \leq \mathrm{TS}<1680$ & Proper \\
\hline 12 & & Sindang Sari & 1003 & $644 \leq \mathrm{TS}<1008$ & Fairly Proper \\
\hline 13 & & Argo Sari & 982 & $644 \leq \mathrm{TS}<1008$ & Fairly Proper \\
\hline 1 & & Tinting & 987 & $644 \leq \mathrm{TS}<1008$ & Fairly Proper \\
\hline 2 & & Sungai Baung & 894 & $644 \leq \mathrm{TS}<1008$ & Fairly Proper \\
\hline 3 & & Panti & 998 & $644 \leq \mathrm{TS}<1008$ & Fairly Proper \\
\hline 4 & & Sungai Abang & 889 & $644 \leq \mathrm{TS}<1008$ & Fairly Proper \\
\hline 5 & & Bernai & 1027 & $1008 \leq \mathrm{TS}<1680$ & Proper \\
\hline 6 & & Dusun Sarolangun & 1002 & $644 \leq \mathrm{TS}<1008$ & Fairly Proper \\
\hline 7 & & Pasar Sarolangun & 859 & $644 \leq \mathrm{TS}<1008$ & Fairly Proper \\
\hline 8 & & Sukasari & 950 & $644 \leq \mathrm{TS}<1008$ & Fairly Proper \\
\hline 9 & - & Sarolangun Kembang & 1017 & $1008 \leq \mathrm{TS}<1680$ & Proper \\
\hline 10 & & Ladang Panjang & 979 & $644 \leq \mathrm{TS}<1008$ & Fairly Proper \\
\hline 11 & & Lidung & 966 & $644 \leq \mathrm{TS}<1008$ & Fairly Proper \\
\hline 12 & & Baru & 880 & $644 \leq \mathrm{TS}<1008$ & Fairly Proper \\
\hline 13 & & Aur Gading & 1118 & $1008 \leq \mathrm{TS}<1680$ & Proper \\
\hline 14 & & Gunung Kembang & 1055 & $1008 \leq \mathrm{TS}<1680$ & Proper \\
\hline 15 & & Ujung Tanjung & 982 & $644 \leq \mathrm{TS}<1008$ & Fairly Proper \\
\hline 16 & & Bernai Dalam & 978 & $644 \leq \mathrm{TS}<1008$ & Fairly Proper \\
\hline 1 & & Tanjung Gagak & 926 & $644 \leq \mathrm{TS}<1008$ & Fairly Proper \\
\hline 2 & & Rantau Gedang & 971 & $644 \leq \mathrm{TS}<1008$ & Fairly Proper \\
\hline 3 & & PulaBuayo & 952 & $644 \leq \mathrm{TS}<1008$ & Fairly Proper \\
\hline 4 & & Batu Penyabung & 881 & $644 \leq \mathrm{TS}<1008$ & Fairly Proper \\
\hline 5 & & Teluk Kecimbung & 900 & $644 \leq \mathrm{TS}<1008$ & Fairly Proper \\
\hline 6 & & Dusun Dalam & 959 & $644 \leq \mathrm{TS}<1008$ & Fairly Proper \\
\hline 7 & & Pulau Lintang & 953 & $644 \leq \mathrm{TS}<1008$ & Fairly Proper \\
\hline 8 & Batin VIII & Penarun & 954 & $644 \leq \mathrm{TS}<1008$ & Fairly Proper \\
\hline 9 & & Pulau Melako & 855 & $644 \leq \mathrm{TS}<1008$ & Fairly Proper \\
\hline 10 & & Tanjung & 1017 & $1008 \leq \mathrm{TS}<1680$ & Proper \\
\hline 11 & & Limbur Tembesi & 971 & $644 \leq \mathrm{TS}<1008$ & Fairly Proper \\
\hline 12 & & Bangun Jayo & 978 & $644 \leq \mathrm{TS}<1008$ & Fairly Proper \\
\hline 13 & & Muara Lati & 917 & $644 \leq \mathrm{TS}<1008$ & Fairly Proper \\
\hline 14 & & Teluk Mancur & 870 & $644 \leq \mathrm{TS}<1008$ & Fairly Proper \\
\hline 15 & & Suka Jadi & 957 & $644 \leq \mathrm{TS}<1008$ & Fairly Proper \\
\hline 1 & & Seko Besar & 904 & $644 \leq \mathrm{TS}<1008$ & Fairly Proper \\
\hline 2 & Pauh & Taman Bandung & 940 & $644 \leq \mathrm{TS}<1008$ & Fairly Proper \\
\hline 3 & & Sepintun & 872 & $644 \leq \mathrm{TS}<1008$ & Fairly Proper \\
\hline
\end{tabular}




\section{Continued}

\begin{tabular}{|c|c|c|c|c|c|}
\hline 4 & & Lamban Sigatal & 869 & $644 \leq \mathrm{TS}<1008$ & Fairly Proper \\
\hline 5 & & Lubuk Napal & 953 & $644 \leq \mathrm{TS}<1008$ & Fairly Proper \\
\hline 6 & & Pengidaran & 984 & $644 \leq \mathrm{TS}<1008$ & Fairly Proper \\
\hline 7 & & Karang Mendapo & 1034 & $1008 \leq \mathrm{TS}<1680$ & Proper \\
\hline 8 & & Batu Ampar & 910 & $644 \leq \mathrm{TS}<1008$ & Fairly Proper \\
\hline 9 & & Batu Kucing & 846 & $644 \leq \mathrm{TS}<1008$ & Fairly Proper \\
\hline 10 & & Pauh & 990 & $644 \leq \mathrm{TS}<1008$ & Fairly Proper \\
\hline 11 & & Semaran & 1011 & $1008 \leq \mathrm{TS}<1680$ & Proper \\
\hline 12 & & Kasang Melintang & 849 & $644 \leq \mathrm{TS}<1008$ & Fairly Proper \\
\hline 13 & & Pangkal Bulian & 848 & $644 \leq \mathrm{TS}<1008$ & Fairly Proper \\
\hline 14 & & Danau Serdang & 862 & $644 \leq \mathrm{TS}<1008$ & Fairly Proper \\
\hline 1 & & Lubuk Kepayang & 880 & $644 \leq \mathrm{TS}<1008$ & Fairly Proper \\
\hline 2 & & Desa Baru & 1007 & $644 \leq \mathrm{TS}<1008$ & Fairly Proper \\
\hline 3 & & Semurung & 995 & $644 \leq \mathrm{TS}<1008$ & Fairly Proper \\
\hline 4 & & Jernih & 927 & $644 \leq \mathrm{TS}<1008$ & Fairly Proper \\
\hline 5 & Air Hitam & Lubuk Jering & 970 & $644 \leq \mathrm{TS}<1008$ & Fairly Proper \\
\hline 6 & & Mentawak Baru & 1079 & $1008 \leq \mathrm{TS}<1680$ & Proper \\
\hline 7 & & Pematang Kabau & 1069 & $1008 \leq \mathrm{TS}<1680$ & Proper \\
\hline 8 & & Bukit Suban & 987 & $644 \leq \mathrm{TS}<1008$ & Fairly Proper \\
\hline 9 & & Mentawak Ulu & 1013 & $1008 \leq \mathrm{TS}<1680$ & Proper \\
\hline 1 & & Mandiangin Tuo & 874 & $644 \leq \mathrm{TS}<1008$ & Fairly Proper \\
\hline 2 & & Mandiangin & 958 & $644 \leq \mathrm{TS}<1008$ & Fairly Proper \\
\hline 3 & & Taman Dewa & 999 & $644 \leq \mathrm{TS}<1008$ & Fairly Proper \\
\hline 4 & & Simpang Kertopati & 878 & $644 \leq \mathrm{TS}<1008$ & Fairly Proper \\
\hline 5 & & Rangkiling & 861 & $644 \leq \mathrm{TS}<1008$ & Fairly Proper \\
\hline 6 & & Rangkiling Simpang & 913 & $644 \leq \mathrm{TS}<1008$ & Fairly Proper \\
\hline 7 & & Gurun Tuo & 878 & $644 \leq \mathrm{TS}<1008$ & Fairly Proper \\
\hline 8 & & Gurun Tuo Simpang & 913 & $644 \leq \mathrm{TS}<1008$ & Fairly Proper \\
\hline 9 & Mandiangin & Kertopati & 861 & $644 \leq \mathrm{TS}<1008$ & Fairly Proper \\
\hline 10 & & Pemusiran & 982 & $644 \leq \mathrm{TS}<1008$ & Fairly Proper \\
\hline 11 & & Gurun Mudo & 887 & $644 \leq \mathrm{TS}<1008$ & Fairly Proper \\
\hline 12 & & Bukit Peranginan & 1019 & $1008 \leq \mathrm{TS}<1680$ & Proper \\
\hline 13 & & Muaro Ketalo & 969 & $644 \leq \mathrm{TS}<1008$ & Fairly Proper \\
\hline 14 & & Guruh Baru & 954 & $644 \leq \mathrm{TS}<1008$ & Fairly Proper \\
\hline 15 & & Petiduran Baru & 970 & $644 \leq \mathrm{TS}<1008$ & Fairly Proper \\
\hline 16 & & Butang Baru & 1047 & $1008 \leq \mathrm{TS}<1680$ & Proper \\
\hline 17 & & Meranti Baru & 1023 & $1008 \leq \mathrm{TS}<1680$ & Proper \\
\hline
\end{tabular}




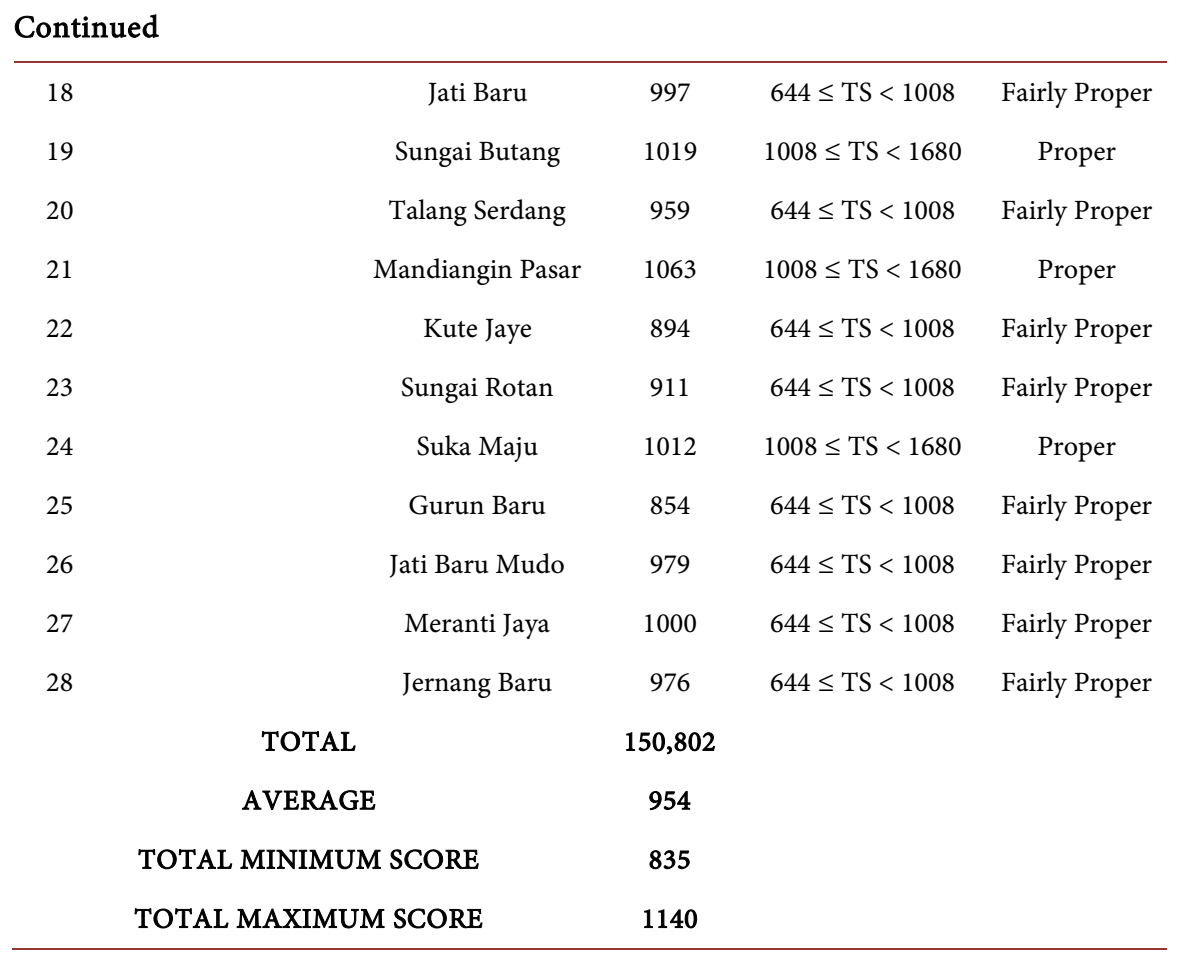

Source: Data Processing, 2017.

Table 8. Comparison potential of villages in Sarolangun regency.

\begin{tabular}{|c|c|c|c|c|c|c|}
\hline NO & DISTRICT & VILLAGE & SCORE & DIFFERENCE & PERCENTAGE & $\begin{array}{c}\text { NOMINATED } \\
\text { VILLAGE }\end{array}$ \\
\hline 1 & & Pekan Gedang & 1041 & 206 & 25 & 2 \\
\hline 2 & & Bukit Kalimau Ulu & 868 & 33 & 4 & 1 \\
\hline 3 & & Raden Anom & 1011 & 176 & 21 & 2 \\
\hline 4 & & Pulau Salak Baru & 857 & 22 & 3 & 1 \\
\hline 5 & & Rantau Panjang & 947 & 112 & 13 & 1 \\
\hline 6 & & Padang Jering & 843 & 8 & 1 & 1 \\
\hline 7 & & Kasiro & 939 & 104 & 12 & 1 \\
\hline 8 & & Kasiro Ilir & 847 & 12 & 1 & 1 \\
\hline 9 & Batang Asai & Datuk Nan Duo & 941 & 106 & 13 & 1 \\
\hline 10 & & Sungai Baung & 901 & 66 & 8 & 1 \\
\hline 11 & & Sungai Bemban & 835 & - & - & 1 \\
\hline 12 & & Lubuk Bangkar & 859 & 24 & 3 & 1 \\
\hline 13 & & Muara Pemuat & 862 & 27 & 3 & 1 \\
\hline 14 & & Muara Cuban & 872 & 37 & 4 & 1 \\
\hline 15 & & Batu Empang & 1009 & 174 & 21 & 2 \\
\hline 16 & & Bathin Pengambang & 1014 & 179 & 21 & 2 \\
\hline 17 & & Tambak Ratu & 1028 & 193 & 23 & 2 \\
\hline 18 & & Muara Air Dua & 1018 & 183 & 22 & 2 \\
\hline
\end{tabular}




\section{Continued}

\begin{tabular}{|c|c|c|c|c|c|c|}
\hline 19 & & Simpang Narso & 877 & 42 & 5 & 1 \\
\hline 20 & & Sungai Keradak & 893 & 58 & 7 & 1 \\
\hline 21 & & Bukit Sulah & 907 & 72 & 9 & 1 \\
\hline 22 & & Paniban Baru & 883 & 48 & 6 & 1 \\
\hline 23 & & Bukit Berantai & 884 & 49 & 6 & 1 \\
\hline 1 & & Mersip & 964 & 105 & 12 & 1 \\
\hline 2 & & Berkun & 918 & 59 & 7 & 1 \\
\hline 3 & & Lubuk Bedorong & 890 & 31 & 4 & 1 \\
\hline 4 & & Meribung & 862 & 3 & 0 & 1 \\
\hline 5 & & Napal Melintang & 898 & 39 & 5 & 1 \\
\hline 6 & & Panca Karya & 947 & 88 & 10 & 1 \\
\hline 7 & & Demang & 932 & 73 & 8 & 1 \\
\hline 8 & & Ranggo & 923 & 64 & 7 & 1 \\
\hline 9 & 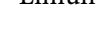 & Muara Mensao & 990 & 131 & 15 & 1 \\
\hline 10 & & Tanjung Raden & 889 & 30 & 3 & 1 \\
\hline 11 & & Temenggung & 915 & 56 & 7 & 1 \\
\hline 12 & & Mounti & 932 & 73 & 8 & 1 \\
\hline 13 & & Pulau Pandan & 974 & 115 & 13 & 1 \\
\hline 14 & & Muara Limun & 1022 & 163 & 19 & 2 \\
\hline 15 & & Suka Damai & 859 & - & - & 1 \\
\hline 16 & & Temalang & 960 & 101 & 12 & 1 \\
\hline 1 & & Lubuk Resam & 1016 & 142 & 16 & 2 \\
\hline 2 & & Lubuk Resam Ilir & 983 & 109 & 12 & 1 \\
\hline 3 & & Tendah & 895 & 21 & 2 & 1 \\
\hline 4 & & Teluk Rendah & 930 & 56 & 6 & 1 \\
\hline 5 & $\begin{array}{c}\text { Cermin } \\
\text { Nan }\end{array}$ & Teluk Tigo & 974 & 100 & 1 & 1 \\
\hline 6 & Gedang & Sungai Keramat & 957 & 83 & 9 & 1 \\
\hline 7 & & Kampung Tujuh & 961 & 87 & 10 & 1 \\
\hline 8 & & Pemuncak & 874 & - & - & 1 \\
\hline 9 & & Tambang Tinggi & 986 & 112 & 13 & 1 \\
\hline 10 & & Sekamis & 884 & 10 & 1 & 1 \\
\hline 1 & & Pematang Kolim & 1052 & 131 & 14 & 2 \\
\hline 2 & & Batu Putih & 1070 & 149 & 16 & 2 \\
\hline 3 & & Pelawan & 950 & 29 & 3 & 1 \\
\hline 4 & Felawan & Sungai Merah & 1042 & 121 & 13 & 2 \\
\hline 5 & & Penegah & 1040 & 119 & 13 & 2 \\
\hline 6 & & Pulau Aro & 1024 & 103 & 11 & 2 \\
\hline
\end{tabular}




\section{Continued}

\begin{tabular}{|c|c|c|c|c|c|c|}
\hline 7 & & Bukit & 959 & 38 & 4 & 1 \\
\hline 8 & & Lubuk Sepuh & 1120 & 199 & 22 & 2 \\
\hline 9 & & Muara Danau & 986 & 65 & 7 & 1 \\
\hline 10 & & Rantau Tenang & 935 & 14 & 2 & 1 \\
\hline 11 & & Mekarsari & 1046 & 125 & 14 & 2 \\
\hline 12 & & Pasar Pelawan & 985 & 64 & 7 & 1 \\
\hline 13 & & Pelawan Jaya & 1042 & 121 & 13 & 2 \\
\hline 14 & & Lubuk Sayak & 921 & - & - & 1 \\
\hline 1 & & Perdamaian & 955 & 81 & 9 & 1 \\
\hline 2 & & Sungai Gedang & 1002 & 128 & 15 & 1 \\
\hline 3 & & Sungai Benteng & 1012 & 138 & 16 & 2 \\
\hline 4 & & Bukit Murau & 1064 & 190 & 22 & 2 \\
\hline 5 & & Pasar Singkut & 1093 & 219 & 25 & 2 \\
\hline 6 & & Bukit Tigo & 874 & - & - & 1 \\
\hline 7 & Singkut & Payo Lebar & 1140 & 266 & 30 & 2 \\
\hline 8 & & Simpang Nibung & 885 & 11 & 1 & 1 \\
\hline 9 & & Siliwangi & 1029 & 155 & 18 & 2 \\
\hline 10 & & Bukit Talang Mas & 1001 & 127 & 15 & 1 \\
\hline 11 & & Bukit Bumi Raya & 1028 & 154 & 18 & 2 \\
\hline 12 & & Sindang Sari & 1003 & 129 & 15 & 1 \\
\hline 13 & & Argo Sari & 982 & 108 & 12 & 1 \\
\hline 1 & & Tinting & 987 & 128 & 15 & 1 \\
\hline 2 & & Sungai Baung & 894 & 35 & 4 & 1 \\
\hline 3 & & Panti & 998 & 139 & 16 & 1 \\
\hline 4 & & Sungai Abang & 889 & 30 & 3 & 1 \\
\hline 5 & & Bernai & 1027 & 168 & 20 & 2 \\
\hline 6 & & Dusun Sarolangun & 1002 & 143 & 17 & 1 \\
\hline 7 & & Pasar Sarolangun & 859 & - & - & 1 \\
\hline 8 & Sarolangun & Sukasari & 950 & 91 & 11 & 1 \\
\hline 9 & & Sarolangun Kembang & 1017 & 158 & 18 & 2 \\
\hline 10 & & Ladang Panjang & 979 & 120 & 14 & 1 \\
\hline 11 & & Lidung & 966 & 107 & 12 & 1 \\
\hline 12 & & Baru & 880 & 21 & 2 & 1 \\
\hline 13 & & Aur Gading & 1118 & 259 & 30 & 2 \\
\hline 14 & & Gunung Kembang & 1055 & 196 & 23 & 2 \\
\hline 15 & & Ujung Tanjung & 982 & 123 & 14 & 1 \\
\hline 16 & & Bernai Dalam & 978 & 119 & 14 & 1 \\
\hline
\end{tabular}




\section{Continued}

\begin{tabular}{|c|c|c|c|c|c|c|}
\hline 1 & & Tanjung Gagak & 926 & 71 & 8 & 1 \\
\hline 2 & & Rantau Gedang & 971 & 116 & 14 & 1 \\
\hline 3 & & Pulau Buayo & 952 & 97 & 11 & 1 \\
\hline 4 & & Batu Penyabung & 881 & 26 & 3 & 1 \\
\hline 5 & & Teluk Kecimbung & 900 & 45 & 5 & 1 \\
\hline 6 & & Dusun Dalam & 959 & 104 & 12 & 1 \\
\hline 7 & & Pulau Lintang & 953 & 98 & 11 & 1 \\
\hline 8 & Batin VIII & Penarun & 954 & 99 & 12 & 1 \\
\hline 9 & & Pulau Melako & 855 & - & - & 1 \\
\hline 10 & & Tanjung & 1017 & 162 & 19 & 2 \\
\hline 11 & & Limbur Tembesi & 971 & 116 & 14 & 1 \\
\hline 12 & & Bangun Jayo & 978 & 123 & 14 & 1 \\
\hline 13 & & Muara Lati & 917 & 62 & 7 & 1 \\
\hline 14 & & Teluk Mancur & 870 & 15 & 2 & 1 \\
\hline 15 & & Suka Jadi & 957 & 102 & 12 & 1 \\
\hline 1 & & Seko Besar & 904 & 58 & 7 & 1 \\
\hline 2 & & Taman Bandung & 940 & 94 & 11 & 1 \\
\hline 3 & & Sepintun & 872 & 26 & 3 & 1 \\
\hline 4 & & Lamban Sigatal & 869 & 23 & 3 & 1 \\
\hline 5 & & Lubuk Napal & 953 & 107 & 13 & 1 \\
\hline 6 & & Pengidaran & 984 & 138 & 16 & 1 \\
\hline 7 & Pauh & Karang Mendapo & 1034 & 188 & 22 & 2 \\
\hline 8 & & Batu Ampar & 910 & 64 & 8 & 1 \\
\hline 9 & & Batu Kucing & 846 & - & - & 1 \\
\hline 10 & & Pauh & 990 & 144 & 17 & 1 \\
\hline 11 & & Semaran & 1011 & 165 & 20 & 2 \\
\hline 12 & & Kasang Melintang & 849 & 3 & 0 & 1 \\
\hline 13 & & Pangkal Bulian & 848 & 2 & 0 & 1 \\
\hline 14 & & Danau Serdang & 862 & 16 & 2 & 1 \\
\hline 1 & & Lubuk Kepayang & 880 & - & - & 1 \\
\hline 2 & & Desa Baru & 1007 & 127 & 14 & 1 \\
\hline 3 & & Semurung & 995 & 115 & 13 & 1 \\
\hline 4 & & Jernih & 927 & 47 & 5 & 1 \\
\hline 5 & Air Hitam & Lubuk Jering & 970 & 90 & 10 & 1 \\
\hline 6 & & Mentawak Baru & 1079 & 199 & 23 & 2 \\
\hline 7 & & Pematang Kabau & 1069 & 189 & 21 & 2 \\
\hline 8 & & Bukit Suban & 987 & 107 & 12 & 1 \\
\hline 9 & & Mentawak Ulu & 1013 & 133 & 15 & 2 \\
\hline
\end{tabular}




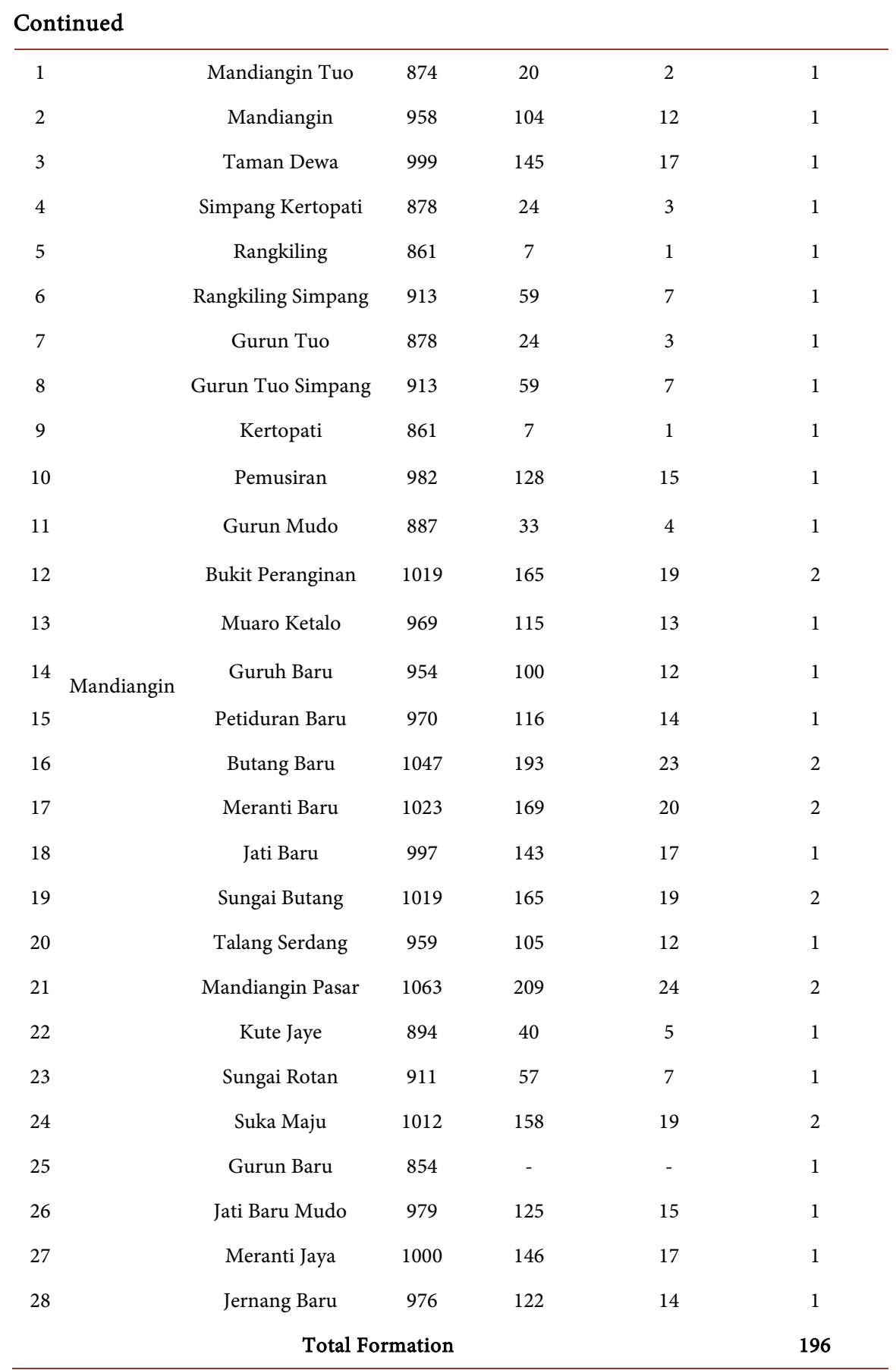

Source: Data Processing, 2017.

Dua, Sungai Keradak, Simpang Narso, Bukit Berantai, Batu Empang, Paniban Baru, Rantau Panjang, and Pulau Salak Baru (Table 10). And parent district with nominated villages of Pekan Gedang, Bukit Kalimau Ulu, Raden Anom, Padang Jering, Kasiro, Kasiro Ilir, Datuk Nan Duo, Sungai Baung, Sungai Bemban, Lubuk Bangkar, Muara Pemuat, Muara Cuban, and Bukit Sulah. Mapping of villages in Batang Asai in alternative 1 can be pictured in map as follows (Figure 2). 
Table 9. Potential of villages in Batang Asai district, Sarolangun regency.

\begin{tabular}{|c|c|c|c|c|c|}
\hline NO & DISTRICT & VILLAGE & $\begin{array}{l}\text { TOTAL } \\
\text { SCORE }\end{array}$ & SCORE INTERVAL & CATEGORY \\
\hline 1 & & Pekan Gedang & 1041 & $1008 \leq \mathrm{TS}<1680$ & Proper \\
\hline 2 & & Bukit Kalimau Ulu & 868 & $644 \leq \mathrm{TS}<1008$ & Fairly Proper \\
\hline 3 & & Raden Anom & 1011 & $1008 \leq \mathrm{TS}<1680$ & Proper \\
\hline 4 & & Pulau Salak Baru & 857 & $644 \leq \mathrm{TS}<1008$ & Fairly Proper \\
\hline 5 & & Rantau Panjang & 947 & $644 \leq \mathrm{TS}<1008$ & Fairly Proper \\
\hline 6 & & Padang Jering & 843 & $644 \leq \mathrm{TS}<1008$ & Fairly Proper \\
\hline 7 & & Kasiro & 939 & $644 \leq \mathrm{TS}<1008$ & Fairly Proper \\
\hline 8 & & Kasiro Ilir & 847 & $644 \leq \mathrm{TS}<1008$ & Fairly Proper \\
\hline 9 & & Datuk Nan Duo & 941 & $644 \leq \mathrm{TS}<1008$ & Fairly Proper \\
\hline 10 & & Sungai Baung & 901 & $644 \leq \mathrm{TS}<1008$ & Fairly Proper \\
\hline 11 & & Sungai Bemban & 835 & $644 \leq \mathrm{TS}<1008$ & Fairly Proper \\
\hline 12 & Batang Asai & Lubuk Bangkar & 859 & $644 \leq \mathrm{TS}<1008$ & Fairly Proper \\
\hline 13 & & Muara Pemuat & 862 & $644 \leq \mathrm{TS}<1008$ & Fairly Proper \\
\hline 14 & & Muara Cuban & 872 & $644 \leq \mathrm{TS}<1008$ & Fairly Proper \\
\hline 15 & & Batu Empang & 1009 & $1008 \leq \mathrm{TS}<1680$ & Proper \\
\hline 16 & & Bathin Pengambang & 1014 & $1008 \leq \mathrm{TS}<1680$ & Proper \\
\hline 17 & & Tambak Ratu & 1028 & $1008 \leq \mathrm{TS}<1680$ & Proper \\
\hline 18 & & Muara Air Dua & 1018 & $1008 \leq$ TS $<1680$ & Proper \\
\hline 19 & & Simpang Narso & 877 & $644 \leq \mathrm{TS}<1008$ & Fairly Proper \\
\hline 20 & & Sungai Keradak & 893 & $644 \leq \mathrm{TS}<1008$ & Fairly Proper \\
\hline 21 & & Bukit Sulah & 907 & $644 \leq \mathrm{TS}<1008$ & Fairly Proper \\
\hline 22 & & Paniban Baru & 883 & $644 \leq \mathrm{TS}<1008$ & Fairly Proper \\
\hline 23 & & Bukit Berantai & 884 & $644 \leq \mathrm{TS}<1008$ & Fairly Proper \\
\hline \multicolumn{3}{|c|}{ TOTAL } & 21136 & & \\
\hline \multicolumn{3}{|c|}{ AVERAGE } & 919 & & \\
\hline \multicolumn{3}{|c|}{ TOTAL MINIMUM SCORE } & 835 & & \\
\hline \multicolumn{3}{|c|}{ TOTAL MAXIMUM SCORE } & 1041 & & \\
\hline
\end{tabular}

Source: Data Processing, 2017.

\section{2) Alternative 2 of Formation of Batang Asai District}

Mapping of villages in Batang Asai District in alternative 2 (Table 11) is the formed district with nominated villages of Batin Pengambang, Tambak Ratu, Muara Air Dua, Sungai Keradak, Simpang Narso, Bukit Berantai, Batu Empang and Batu Empang. And parent district with nominated villages of Pekan Gedang, Bukit Kalimau Ulu, Raden Anom, Pulau Salak Baru, Rantau Panjang, Padang Jering, Kasiro, Kasiro Ilir, Datuk Nan Duo, Sungai Baung, Sungai Bemban, 
Table 10. Mapping of villages in Batang Asai district.

\begin{tabular}{|c|c|c|c|c|c|c|}
\hline NO & $\begin{array}{l}\text { ORMED } \\
\text { DISTRICT }\end{array}$ & Nominated Village & $\begin{array}{l}\text { Total } \\
\text { Score }\end{array}$ & $\begin{array}{l}\text { PARENT } \\
\text { DISTRICT }\end{array}$ & Nominated Village & Total Score \\
\hline 1 & & Batin Pengambang & 1014 & & Pekan Gedang & 1041 \\
\hline 2 & & Tambak Ratu & 1028 & & Bukit Kalimau Ulu & 868 \\
\hline 3 & & Muara Air Dua & 1018 & & Raden Anom & 1011 \\
\hline 4 & & Sungai Keradak & 893 & & Padang Jering & 843 \\
\hline 5 & & Simpang Narso & 877 & & Kasiro & 939 \\
\hline 6 & & Bukit Berantai & 884 & & Kasiro Ilir & 847 \\
\hline 7 & & Batu Empang & 1009 & & Datuk Nan Duo & 941 \\
\hline 8 & & Paniban Baru & 883 & & Sungai Baung & 901 \\
\hline 9 & & Rantau Panjang & 947 & & Sungai Bemban & 835 \\
\hline 10 & & Pulau Salak Baru & 857 & & Lubuk Bangkar & 859 \\
\hline 11 & & & & & Muara Pemuat & 862 \\
\hline 12 & & & & & Muara Cuban & 872 \\
\hline 13 & & & & & Bukit Sulah & 907 \\
\hline \multicolumn{3}{|c|}{ TOTAL } & 9,410 & & & 11,726 \\
\hline \multicolumn{3}{|c|}{ AVERAGE } & 941 & & & 902 \\
\hline \multicolumn{3}{|c|}{ TOTAL MINIMUM SCORE } & 857 & & & 835 \\
\hline \multicolumn{3}{|c|}{ TOTAL MAXIMUM SCORE } & 1028 & & & 1041 \\
\hline
\end{tabular}

Source: Data Processing, 2017.

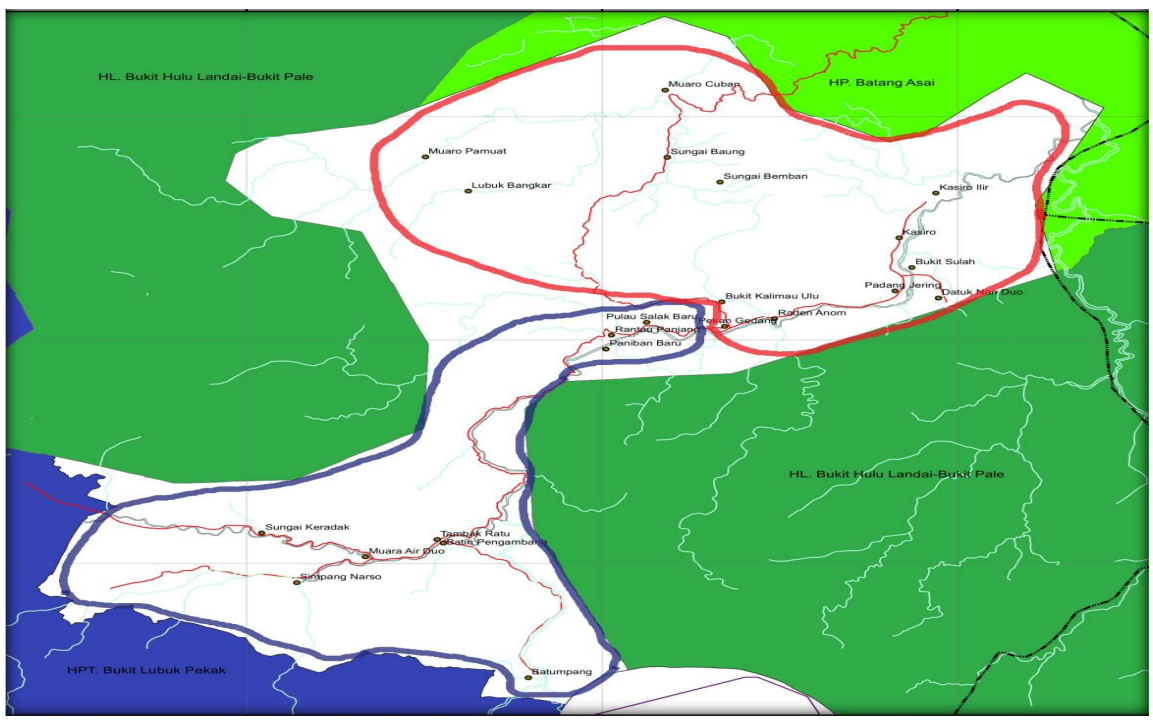

Figure 2. Mapping of Villages of Batang Asai district in alternative 1. Source: Data Processing, 2017.

Lubuk Bangkar, Muara Pemuat, Muara Cuban, Bukit Sulah, and Paniban Baru. Mapping of villages in Batang Asai in alternative 2 can be pictured in map as follows (Figure 3). 


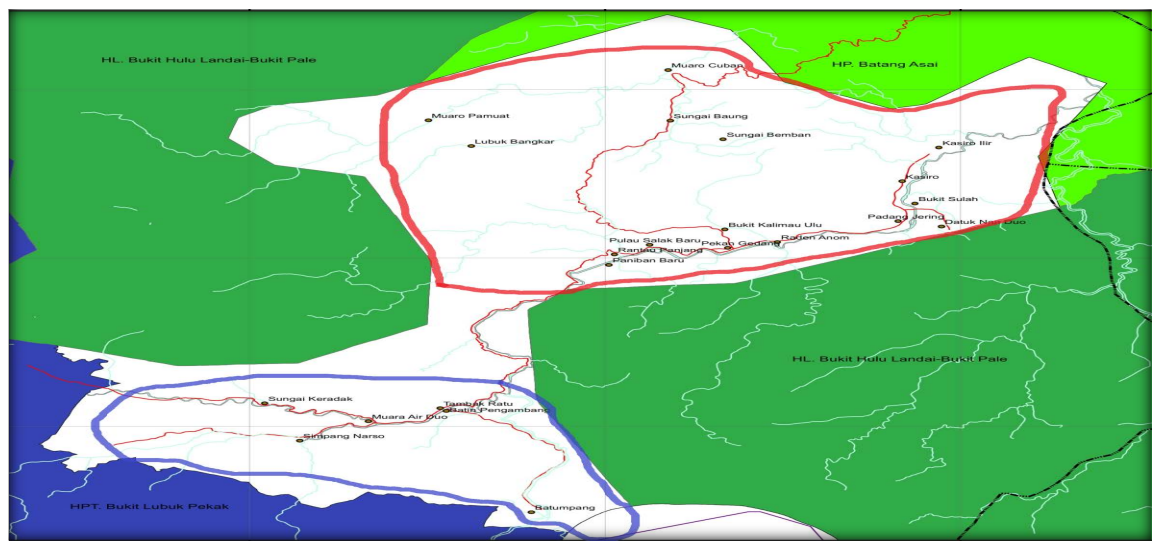

Figure 3. Mapping of Villages of Batang Asai District in Alternative 2 Source: Data Processing, 2017.

Table 11. Mapping of Villages in Batang Asai District Alternative 2.

\begin{tabular}{|c|c|c|c|c|c|c|}
\hline \multirow[t]{2}{*}{ NO } & FORMED & \multirow[t]{2}{*}{ Nominated Village } & \multirow[t]{2}{*}{$\begin{array}{l}\text { Total } \\
\text { Score }\end{array}$} & \multirow{2}{*}{$\begin{array}{c}\text { PARENT } \\
\text { DISTRICT }\end{array}$} & \multirow[t]{2}{*}{ Nominated Village } & \multirow[t]{2}{*}{$\begin{array}{l}\text { Total } \\
\text { Score }\end{array}$} \\
\hline & DISTRICT & & & & & \\
\hline 1 & & Batin Pengambang & 1014 & & Pekan Gedang & 1041 \\
\hline 2 & & Tambak Ratu & 1028 & & Bukit Kalimau Ulu & 868 \\
\hline 3 & & Muara Air Dua & 1018 & & Raden Anom & 1011 \\
\hline 4 & & Sungai Keradak & 893 & & Pulau Salak Baru & 857 \\
\hline 5 & & Simpang Narso & 877 & & Rantau Panjang & 947 \\
\hline 6 & & Bukit Berantai & 884 & & Padang Jering & 843 \\
\hline 7 & & Batu Empang & 1009 & & Kasiro & 939 \\
\hline 8 & & & & & Kasiro Ilir & 847 \\
\hline 9 & & & & & Datuk Nan Duo & 941 \\
\hline 10 & & & & & Sungai Baung & 901 \\
\hline 11 & & & & & Sungai Bemban & 835 \\
\hline 12 & & & & & Lubuk Bangkar & 859 \\
\hline 13 & & & & & Muara Pemuat & 862 \\
\hline 14 & & & & & Muara Cuban & 872 \\
\hline 15 & & & & & Bukit Sulah & 907 \\
\hline 16 & & & & & Paniban Baru & 883 \\
\hline & & TAL & 6,723 & & & 14,413 \\
\hline & $\mathrm{AVE}$ & RAGE & 960 & & & 901 \\
\hline & TOTAL MIN & MUM SCORE & 877 & & & 835 \\
\hline & TOTAL MAX & IMUM SCORE & 1028 & & & 1041 \\
\hline
\end{tabular}

Source: Data Processing, 2017.

\section{3) Alternative 3 of Formation of Batang Asai District}

Mapping of villages in Batang Asai District in alternative 3 (Table 12) is the formed district 1 with nominated villages of Batin Pengambang, Tambak Ratu, 
Table 12. Mapping of villages in Batang Asai district alternative 3.

\begin{tabular}{|c|c|c|c|c|c|c|c|}
\hline $\begin{array}{c}\text { NO FORMED } \\
\text { DISTRICT } \\
1\end{array}$ & $\begin{array}{l}\text { Nominated } \\
\text { Village }\end{array}$ & $\begin{array}{l}\text { Total } \\
\text { Score }\end{array}$ & $\begin{array}{c}\text { FORMED } \\
\text { DISTRICT } \\
2\end{array}$ & $\begin{array}{l}\text { Nominated } \\
\text { Village }\end{array}$ & $\begin{array}{l}\text { Total PARENT } \\
\text { Score } \text { DISTRICT }\end{array}$ & $\begin{array}{l}\text { Nominated } \\
\text { Village }\end{array}$ & $\begin{array}{l}\text { Total } \\
\text { Score }\end{array}$ \\
\hline 1 & $\begin{array}{c}\text { Batin } \\
\text { Pengambang }\end{array}$ & 1014 & & $\begin{array}{l}\text { Sungai } \\
\text { Baung }\end{array}$ & 901 & $\begin{array}{l}\text { Pekan } \\
\text { Gedang }\end{array}$ & 1041 \\
\hline 2 & Tambak Ratu & 1028 & & $\begin{array}{l}\text { Sungai } \\
\text { Bemban }\end{array}$ & 835 & $\begin{array}{l}\text { Raden } \\
\text { Anom }\end{array}$ & 1011 \\
\hline 3 & $\begin{array}{l}\text { Muara Air } \\
\text { Dua }\end{array}$ & 1018 & & $\begin{array}{l}\text { Lubuk } \\
\text { Bangkar }\end{array}$ & 859 & $\begin{array}{c}\text { Pulau Salak } \\
\text { Baru }\end{array}$ & 857 \\
\hline 4 & $\begin{array}{c}\text { Sungai } \\
\text { Keradak }\end{array}$ & 893 & & $\begin{array}{l}\text { Muara } \\
\text { Pemuat }\end{array}$ & 862 & $\begin{array}{l}\text { Rantau } \\
\text { Panjang }\end{array}$ & 947 \\
\hline 5 & $\begin{array}{c}\text { Simpang } \\
\text { Narso }\end{array}$ & 877 & & $\begin{array}{l}\text { Muara } \\
\text { Cuban }\end{array}$ & 872 & $\begin{array}{l}\text { Padang } \\
\text { Jering }\end{array}$ & 843 \\
\hline 6 & $\begin{array}{c}\text { Bukit } \\
\text { Berantai }\end{array}$ & 884 & & $\begin{array}{c}\text { Bukit } \\
\text { Kalimau } \\
\text { Ulu }\end{array}$ & 868 & Kasiro & 939 \\
\hline 7 & $\begin{array}{l}\text { Batu } \\
\text { Empang }\end{array}$ & 1009 & & & & Kasiro Ilir & 847 \\
\hline 8 & & & & & & $\begin{array}{c}\text { Datuk Nan } \\
\text { Duo }\end{array}$ & 941 \\
\hline 9 & & & & & & Bukit Sulah & 907 \\
\hline 10 & & & & & & $\begin{array}{c}\text { Paniban } \\
\text { Baru }\end{array}$ & 883 \\
\hline \multicolumn{2}{|c|}{ TOTAL } & 6723 & & & 5197 & & 9216 \\
\hline \multicolumn{2}{|c|}{ AVERAGE } & 960 & & & 866 & & 922 \\
\hline \multicolumn{2}{|c|}{$\begin{array}{l}\text { TOTAL MINIMUM } \\
\text { SCORE }\end{array}$} & 877 & & & 835 & & 843 \\
\hline \multicolumn{2}{|c|}{$\begin{array}{l}\text { TOTAL MAXIMUM } \\
\text { SCORE }\end{array}$} & 1028 & & & 901 & & 1041 \\
\hline
\end{tabular}

Source: Data Processing, 2017.

Muara Air Dua, Sungai Keradak, Simpang Narso, Bukit Berantai, and Batu Empang. The formed district 2 with nominated villages of Sungai Baung, Sungai Bemban, Lubuk Bangkar, Muara Pemuat, Muara Cuban, and Kalimau Ulu. And parent district with nominated villages of Pekan Gedang, Raden Anom, Pulau Salak Baru, Rantau Panjang, Padang Jering, Kasiro, Kasiro Ilir, Datuk Nan Duo, Bukit Sulah and Paniban Baru. Mapping of villages in Batang Asai in alternative 3 can be pictured in map as follows (Figure 4).

Next, score difference between Formation of Batang Asai District in alternative 1 , alternative 2 and alternative 3 is calculated.

Based on comparison (Table 13) of potential as shown in table above, it can be explained that in alternative 1, comparison between proposed parent district and proposed formed district is by -39 , which means that proposed parent district has lower potential than proposed formed district. In alternative 2, comparison between proposed parent district and proposed formed district is by -59 , which means that proposed parent district has lower potential than proposed formed district. In alternative 3 , comparison between proposed parent district and proposed formed district 1 is by -38 , which means that proposed parent district has lower potential than proposed formed district 1 , and comparison 


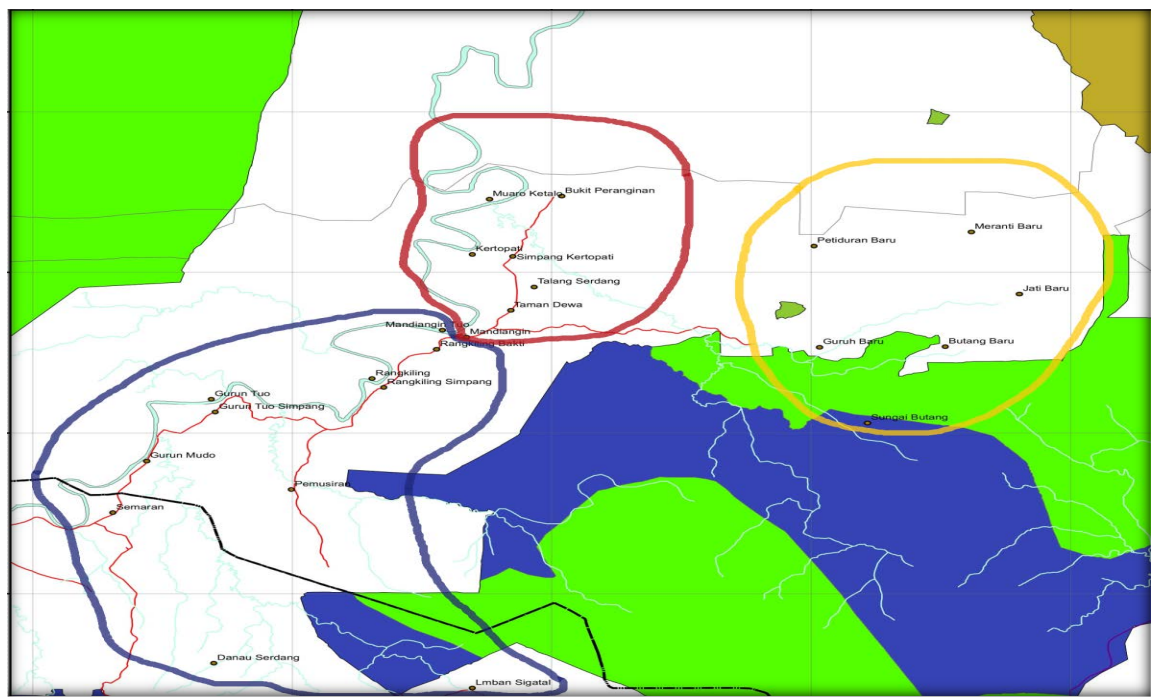

Figure 4. Mapping of Villages of Batang Asai District in Alternative 3. Source: Data Processing, 2017.

Table 13. Difference of mapping of villages in Batang Asai District.

\begin{tabular}{ccccc}
\hline & \multicolumn{3}{c}{ Score Average } \\
\cline { 2 - 4 } Mapping & $\begin{array}{c}\text { Parent } \\
\text { District }\end{array}$ & $\begin{array}{c}\text { Formed } \\
\text { District 1 }\end{array}$ & $\begin{array}{c}\text { Formed } \\
\text { District 2 }\end{array}$ & Difference \\
\hline Alternative 1 & 902 & 941 & & -39 \\
Alternative 2 & 901 & 960 & & -59 \\
Alternative 3 & 922 & 960 & 866 & -38 \\
& & & & 56 \\
\hline
\end{tabular}

Source: Data Processing, 2017.

between proposed parent district and proposed formed district 2 is by 56 , which means that parent district has higher potential than proposed formed district 2 . Therefore, it is clear that alternative 3 is decided to be choice 1 . This is based on consideration that formation according to division of governmental working area is relatively more balanced in terms of potential than formation by alternative 1 and alternative 2 regarding the 19 variables. Differences between parent district and proposed parent district and proposed formed district in alternative 3 are -38 and 56 , while average distance in alternative 2 is -39 and in alternative 3 is -59 . Therefore, it can be concluded that regional reordering by formation of Batang Asai District can be designed in 3 (three) best alternatives of regional reordering as follows:

Regional reordering by formation of Batang Asai District can be designed in 3 (three) best alternatives of regional reordering as follows:

\section{4) Alternative 1 (score difference -39)}

* Proposed parent district with average score of 902 consisting of 19 villages, namely Pekan Gedang, Bukit Kalimau Ulu, Raden Anom, Padang Jering, Ka- 
siro, Kasiro Ilir, Datuk Nan Duo, Sungai Baung, Sungai Bemban, Lubuk Bangkar, Muara Pemuat, Muara Cuban, and Bukit Sulah.

* Proposed formed district with average score of 941 consisting of 10 villages, namely Batin Pengambang, Tambak Ratu, Muara Air Dua, Sungai Keradak, Simpang Narso, Bukit Berantai, Batu Empang, Paniban Baru, Rantau Panjang, and Pulau Salak Baru.

5) Alternative 2 (score difference -59)

* Proposed parent district with average score of 901 consisting of 16 villages, namely Pekan Gedang, Bukit Kalimau Ulu, Raden Anom, Pulau Salak Baru, Rantau Panjang, Padang Jering, Kasiro, Kasiro Ilir, Datuk Nan Duo, Sungai Baung, Sungai Bemban, Lubuk Bangkar, Muara Pemuat, Muara Cuban, Bukit Sulah, and Paniban Baru.

* Proposed formed district with average score of 960 consisting of 7 villages, namely Batin Pengambang, Tambak Ratu, Muara Air Dua, Sungai Keradak, Simpang Narso, Bukit Berantai, and Batu Empang.

6) Alternative 3 (score differences -38 and 56 )

* Proposed parent district with average score of 922 consisting of 10 villages, namely Pekan Gedang, Raden Anom, Pulau Salak Baru, Rantau Panjang, Padang Jering, Kasiro, Kasiro Ilir, Datuk Nan Duo, Bukit Sulah, and Paniban Baru.

* Proposed formed district with average score of 960 consisting of 7 villages, namely Batin Pengambang, Tambak Ratu, Muara Air Dua, Sungai Keradak, Simpang Narso, Bukit Berantai, and Batu Empang.

* Proposed formed district 2 with average score of 866 consisting of 6 villages, namely Sungai Baung, Sungai Bemban, Lubuk Bangkar, Muara Pemuat, $\mathrm{Mu}$ ara Cuban, and Bukit Kalimau Ulu.

\section{b) Formation of Mandiangin District}

Formation of Mandiangin District, as explained above that potential of villages in Mandiangin District, Sarolangun Regency is based on result of study on regional potential of Mandiangin District, Sarolangun Regency by scoring on 19 (nineteen) variables, with category of proper, fairly proper or improper for formation are shown in Table 14 as follows.

Based on result of analysis above, by the mapping of villages in Mandiangin District, Sarolangun Regency, there are 6 (six) villages in the category of proper for formation and 22 (twenty-two) villages in the category of fairly proper for formation. In terms of formation of Mandiangin District, there are 3 (three) alternatives of formation of Mandiangin District.

\section{c) Alternative 1 of Formation of Mandiangin District}

Mapping of villages in Mandiangin District in alternative 1 (Table 15) is the formed district 1 with nominated villages of Guruh Baru, Sungai Butang, Butang Baru, Jati Baru Mudo, Jati Baru, Meranti Baru, Meranti Raya, Jernang Baru and Petiduran Baru. And parent district with nominated villages of Mandiangin Tuo, Mandiangin, Taman Dewa, Simpang Kertopati, Rangkiling, Rangkiling Simpang, Gurun Tuo, Gurun Tuo Simpang, Kertopati, Pemusiran, Gurun Mudo, 
Table 14. Potential of Villages in Mandiangin District, Sarolangun Regency.

\begin{tabular}{|c|c|c|c|c|c|}
\hline NO & DISTRICT & VILLAGE & $\begin{array}{l}\text { TOTAL } \\
\text { SCORE }\end{array}$ & SCORE INTERVAL & CATEGORY \\
\hline 1 & & Mandiangin Tuo & 874 & $644 \leq \mathrm{TS}<1008$ & Fairly Proper \\
\hline 2 & & Mandiangin & 958 & $644 \leq \mathrm{TS}<1008$ & Fairly Proper \\
\hline 3 & & Taman Dewa & 999 & $644 \leq \mathrm{TS}<1008$ & Fairly Proper \\
\hline 4 & & Simpang Kertopati & 878 & $644 \leq \mathrm{TS}<1008$ & Fairly Proper \\
\hline 5 & & Rangkiling & 861 & $644 \leq \mathrm{TS}<1008$ & Fairly Proper \\
\hline 6 & & Rangkiling Simpang & 913 & $644 \leq \mathrm{TS}<1008$ & Fairly Proper \\
\hline 7 & & Gurun Tuo & 878 & $644 \leq \mathrm{TS}<1008$ & Fairly Proper \\
\hline 8 & & Gurun Tuo Simpang & 913 & $644 \leq \mathrm{TS}<1008$ & Fairly Proper \\
\hline 9 & & Kertopati & 861 & $644 \leq \mathrm{TS}<1008$ & Fairly Proper \\
\hline 10 & & Pemusiran & 982 & $644 \leq \mathrm{TS}<1008$ & Fairly Proper \\
\hline 11 & & Gurun Mudo & 887 & $644 \leq \mathrm{TS}<1008$ & Fairly Proper \\
\hline 12 & & Bukit Peranginan & 1019 & $1008 \leq \mathrm{TS}<1680$ & Proper \\
\hline 13 & & Muaro Ketalo & 969 & $644 \leq \mathrm{TS}<1008$ & Fairly Proper \\
\hline 14 & Mandiangin & Guruh Baru & 954 & $644 \leq \mathrm{TS}<1008$ & Fairly Proper \\
\hline 15 & & Petiduran Baru & 970 & $644 \leq \mathrm{TS}<1008$ & Fairly Proper \\
\hline 16 & & Butang Baru & 1047 & $1008 \leq$ TS $<1680$ & Proper \\
\hline 17 & & Meranti Baru & 1023 & $1008 \leq \mathrm{TS}<1680$ & Proper \\
\hline 18 & & Jati Baru & 997 & $644 \leq \mathrm{TS}<1008$ & Fairly Proper \\
\hline 19 & & Sungai Butang & 1019 & $1008 \leq \mathrm{TS}<1680$ & Proper \\
\hline 20 & & Talang Serdang & 959 & $644 \leq \mathrm{TS}<1008$ & Fairly Proper \\
\hline 21 & & Mandiangin Pasar & 1063 & $1008 \leq \mathrm{TS}<1680$ & Proper \\
\hline 22 & & Kute Jaye & 894 & $644 \leq \mathrm{TS}<1008$ & Fairly Proper \\
\hline 23 & & Sungai Rotan & 911 & $644 \leq \mathrm{TS}<1008$ & Fairly Proper \\
\hline 24 & & Suka Maju & 1012 & $1008 \leq \mathrm{TS}<1680$ & Proper \\
\hline 25 & & Gurun Baru & 854 & $644 \leq \mathrm{TS}<1008$ & Fairly Proper \\
\hline 26 & & Jati Baru Mudo & 979 & $644 \leq \mathrm{TS}<1008$ & Fairly Proper \\
\hline 27 & & Meranti Jaya & 1000 & $644 \leq \mathrm{TS}<1008$ & Fairly Proper \\
\hline 28 & & Jernang Baru & 976 & $644 \leq \mathrm{TS}<1008$ & Fairly Proper \\
\hline \multicolumn{3}{|c|}{ TOTAL } & 26,650 & & \\
\hline \multicolumn{3}{|c|}{ AVERAGE } & 952 & & \\
\hline \multicolumn{3}{|c|}{ TOTAL MINIMUM SCORE } & 854 & & \\
\hline \multicolumn{3}{|c|}{ TOTAL MAXIMUM SCORE } & 1063 & & \\
\hline
\end{tabular}

Source: Data Processing, 2017.

Bukit Peranginan, Muaro Ketalo, Talang Serdang, Mandiangin Pasar, Kute Jaye, Sungai Rotan and Gurun Baru. Mapping of villages in Mandiangin District in alternative 1 can be pictured in map as follows (Figure 5). 
Table 15. Mapping of VIllages in Mandiangin district alternative 1.

\begin{tabular}{|c|c|c|c|c|c|c|}
\hline \multirow{2}{*}{ NO } & FORMED & \multirow{2}{*}{$\begin{array}{l}\text { Nominated } \\
\text { Village }\end{array}$} & \multirow{2}{*}{$\begin{array}{l}\text { Total } \\
\text { Score }\end{array}$} & PARENT & \multirow{2}{*}{$\begin{array}{l}\text { Nominated } \\
\text { Village }\end{array}$} & \multirow{2}{*}{$\begin{array}{l}\text { Total } \\
\text { Score }\end{array}$} \\
\hline & DISTRICT & & & DISTRICT & & \\
\hline 1 & & Guruh Baru & 954 & & Mandiangin Tuo & 874 \\
\hline 2 & & Sungai Butang & 1019 & & Mandiangin & 958 \\
\hline 3 & & Butang Baru & 1047 & & Taman Dewa & 999 \\
\hline 4 & & Suka Maju & 1012 & & Simpang Kertopati & 878 \\
\hline 5 & & Jati Baru Mudo & 979 & & Rangkiling & 861 \\
\hline 6 & & Jati Baru & 997 & & $\begin{array}{l}\text { Rangkiling } \\
\text { Simpang }\end{array}$ & 913 \\
\hline 7 & & Meranti Baru & 1023 & & Gurun Tuo & 878 \\
\hline 8 & & Meranti Raya & 1000 & & $\begin{array}{c}\text { Gurun Tuo } \\
\text { Simpang }\end{array}$ & 913 \\
\hline 9 & & Jernang Baru & 976 & & Kertopati & 861 \\
\hline 10 & & Petiduran Baru & 970 & & Pemusiran & 982 \\
\hline 11 & & & & & Gurun Mudo & 887 \\
\hline 12 & & & & & Bukit Peranginan & 1019 \\
\hline 13 & & & & & Muaro Ketalo & 969 \\
\hline 14 & & & & & Talang Serdang & 959 \\
\hline 15 & & & & & Mandiangin Pasar & 1063 \\
\hline 16 & & & & & Kute Jaye & 894 \\
\hline 17 & & & & & Sungai Rotan & 911 \\
\hline \multirow[t]{3}{*}{18} & & & & & Gurun Baru & 854 \\
\hline & \multicolumn{2}{|c|}{ TOTAL } & 9,977 & & & 16,673 \\
\hline & \multicolumn{2}{|c|}{ AVERAGE } & 998 & & & 926 \\
\hline \multicolumn{3}{|c|}{ TOTAL MINIMUM SCORE } & 954 & & & 854 \\
\hline \multicolumn{3}{|c|}{ TOTAL MAXIMUM SCORE } & 1047 & & & 1063 \\
\hline
\end{tabular}

Source: Data Processing, 2017.

\section{d) Alternative 2 of Formation of Mandiangin District}

Mapping of villages in Mandinagin District in alternative 2 (Table 16) is the formed village 1 with nominated villages of Sungai Rotan, Bukit Peranginan, Muaro Ketalo, Simpang Kertopati, Kertopati, Talang Serdang, Taman Dewa, Kute Jaye and Mandiangin Pasar. The formed district 2 with nominated villages of Guruh Baru, Sungai Butang, Butang Baru, Suka Maju, Jati Baru Mudo, Jati Baru, Meranti Baru, Meranti Raya, Jernang Baru and Petiduran Baru. And parent district with nominated villages of Mandiangin, Mandiangin Tuo, Rangkiling, Rangkiling Simpang, Gurun Tuo, Gurun Tuo Simpang, Pemusiran, Gurun Mudo and Gurun Baru. Mapping of villages in Mandiangin District in alternative 2 can be pictured in map as follows (Figure 6).

e) Alternative 3 of Formation of Mandiangin District 


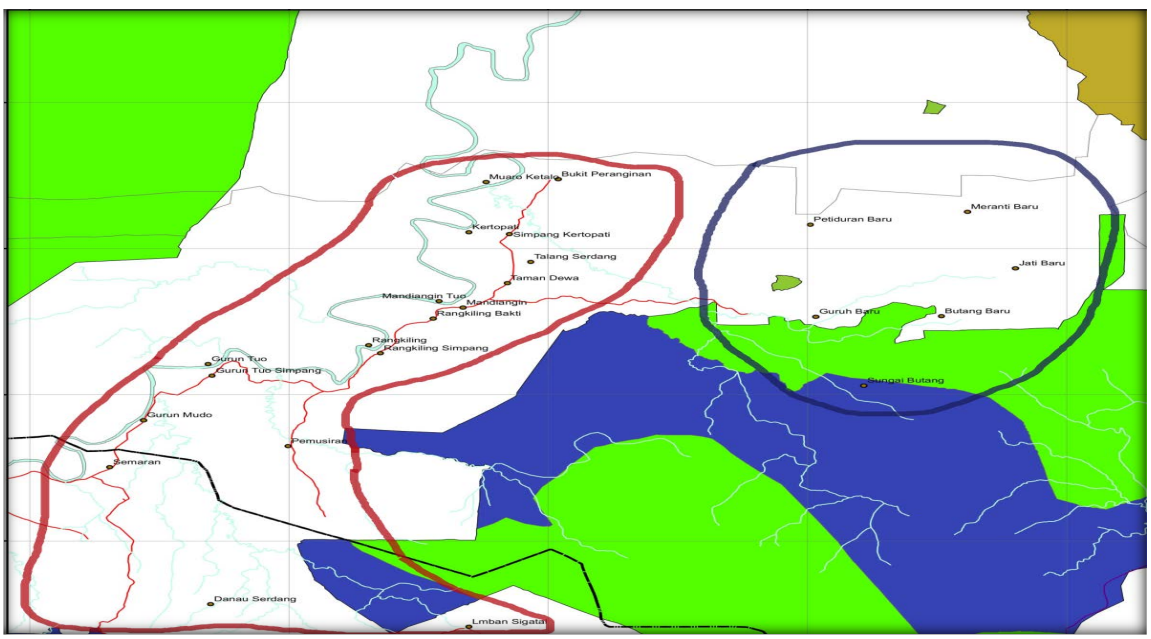

Figure 5. Mapping of Villages of Mandiangin district in alternative 1 Source: Data processing, 2017.

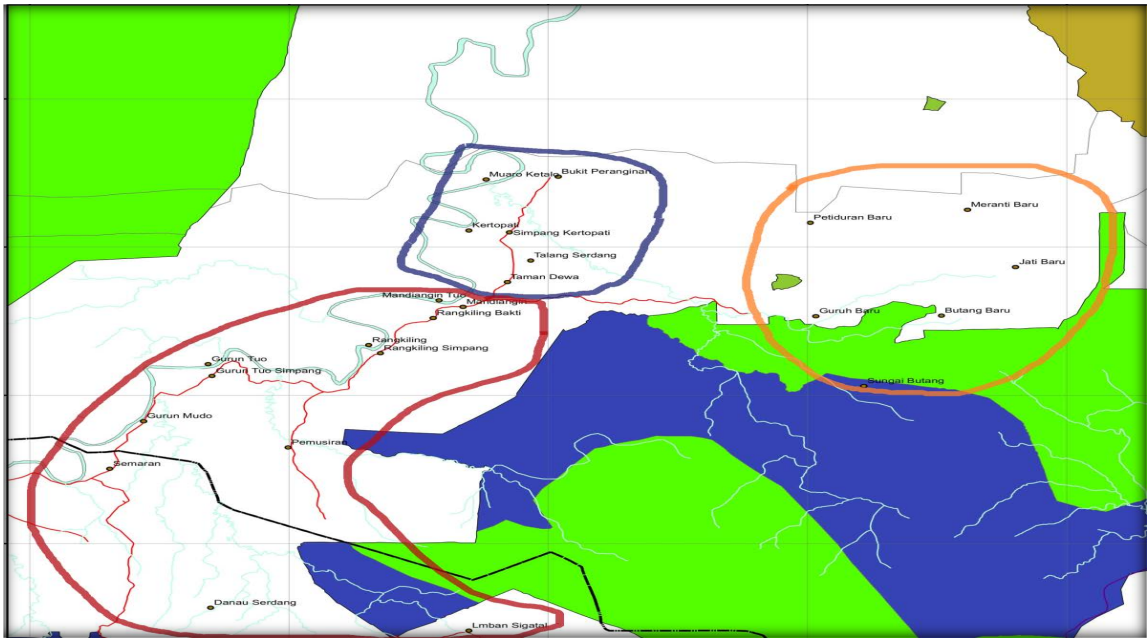

Figure 6. Mapping of villages of Mandiangin district in alternative 2. Source: Data processing, 2017.

Mapping of villages in Mandiangin District in alternative 3 (Table 17) is the formed district 1 with nominated villages of Mandiangin Tuo, Rangkiling, Rangkiling Simpang, Gurun Tuo, Gurun Tuo Simpang, Pemusiran, Gurun Mudo and Gurun Baru. The formed district 2 with nominated villages of Guruh Baru, Sungai Butang, Butang Baru, Suka Maju, Jati Baru Mudo, Jati Baru, Meranti Baru, Meranti Raya, Jernang Baru and Petiduran Baru. And parent district with nominated villages of Sungai Rotan, Bukit Peranginan, Muaro Ketalo, Simpang Kertopati, Kertopati, Talang Serdang, Taman Dewa, Kute Jaye, Mandiangin Pasar and Mandiangin. Mapping of villages in Mandiangin District in alternative 3 can be pictured in map as follows (Figure 7).

Next, score difference between Formation of Mandiangin District in alternative 1, alternative 2 and alternative 3 is calculated:

Based on comparison of potential as shown in Table 18, it can be explained 
Table 16. Mapping of villages in Mandiangin district alternative 2.

\begin{tabular}{|c|c|c|c|c|c|c|c|c|c|}
\hline No & $\begin{array}{c}\text { Formed } \\
\text { District } 1\end{array}$ & $\begin{array}{l}\text { Nominated } \\
\text { Village }\end{array}$ & $\begin{array}{l}\text { Total } \\
\text { Score }\end{array}$ & $\frac{\text { Formed }}{\text { District } 2}$ & $\begin{array}{c}\text { Nominated } \\
\text { Village }\end{array}$ & $\begin{array}{l}\text { Total } \\
\text { Score }\end{array}$ & $\frac{\text { Parent }}{\text { District }}$ & $\begin{array}{c}\text { Nominated } \\
\text { Village }\end{array}$ & $\begin{array}{l}\text { Total } \\
\text { Score }\end{array}$ \\
\hline 1 & & Sungai Rotan & 911 & & Guruh Baru & 954 & & Mandiangin & 958 \\
\hline 2 & & $\begin{array}{c}\text { Bukit } \\
\text { Peranginan }\end{array}$ & 1019 & & $\begin{array}{l}\text { Sungai } \\
\text { Butang }\end{array}$ & 1019 & & $\begin{array}{c}\text { Mandiangin } \\
\text { Tuo }\end{array}$ & 874 \\
\hline 3 & & Muaro Ketalo & 969 & & Butang Baru & 1047 & & Rangkiling & 861 \\
\hline 4 & & $\begin{array}{l}\text { Simpang } \\
\text { Kertopati }\end{array}$ & 878 & & Suka Maju & 1012 & & $\begin{array}{l}\text { Rangkiling } \\
\text { Simpang }\end{array}$ & 913 \\
\hline 5 & & Kertopati & 861 & & $\begin{array}{l}\text { Jati Baru } \\
\text { Mudo }\end{array}$ & 979 & & Gurun Tuo & 878 \\
\hline 6 & & $\begin{array}{l}\text { Talang } \\
\text { Serdang }\end{array}$ & 959 & & Jati Baru & 997 & & $\begin{array}{l}\text { Gurun Tuo } \\
\text { Simpang }\end{array}$ & 913 \\
\hline 7 & & Taman Dewa & 999 & & $\begin{array}{c}\text { Meranti } \\
\text { Baru }\end{array}$ & 1023 & & Pemusiran & 982 \\
\hline 8 & & Kute Jaye & 894 & & $\begin{array}{c}\text { Meranti } \\
\text { Raya }\end{array}$ & 1000 & & $\begin{array}{l}\text { Gurun } \\
\text { Mudo }\end{array}$ & 887 \\
\hline 9 & & $\begin{array}{l}\text { Mandiangin } \\
\text { Pasar }\end{array}$ & 1063 & & $\begin{array}{c}\text { Jernang } \\
\text { Baru }\end{array}$ & 976 & & Gurun Baru & 854 \\
\hline 10 & & & & & $\begin{array}{l}\text { Petiduran } \\
\text { Baru }\end{array}$ & 970 & & & \\
\hline \multicolumn{3}{|c|}{ TOTAL } & 8,553 & & & 9,977 & & & 8,120 \\
\hline \multicolumn{3}{|c|}{ AVERAGE } & 950 & & & 998 & & & 902 \\
\hline \multicolumn{3}{|c|}{ TOTAL MINIMUM SCORE } & 861 & & & 954 & & & 854 \\
\hline \multicolumn{3}{|c|}{ TOTAL MAXIMUM SCORE } & 1063 & & & 1047 & & & 982 \\
\hline
\end{tabular}

Source: Data Processing, 2017.

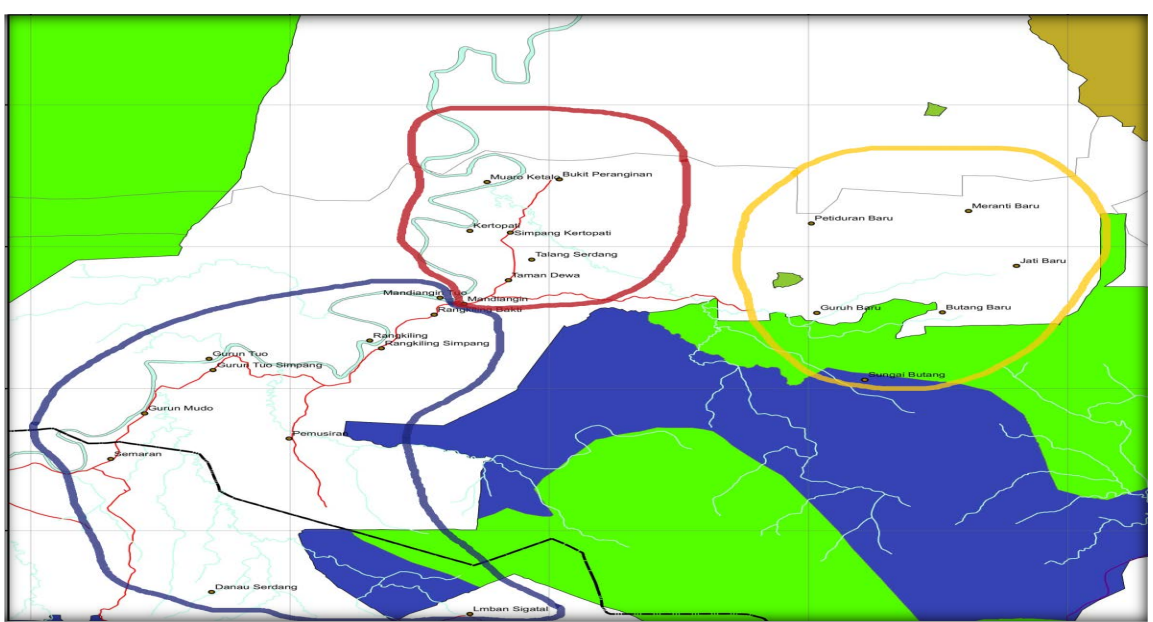

Figure 7. Mapping of villages of Mandiangin district in alternative 3. Source: Data processing, 2017.

that in alternative 1, comparison between proposed parent district and proposed formed district is by -71 , which means that proposed parent district has lower potential than proposed formed district. In alternative 2, comparison between proposed parent district and proposed formed district -48 is by -95 , which 
Table 17. Mapping of villages in Mandiangin district alternative 3.

\begin{tabular}{|c|c|c|c|c|c|c|c|c|c|}
\hline NO & $\begin{array}{c}\text { Formed } \\
\text { District } \\
1\end{array}$ & $\begin{array}{l}\text { Nominated } \\
\text { Village }\end{array}$ & $\begin{array}{l}\text { Total } \\
\text { Score }\end{array}$ & $\frac{\text { Formed }}{\text { District } 2}$ & $\begin{array}{l}\text { Nominated } \\
\text { Village }\end{array}$ & $\begin{array}{l}\text { Total } \\
\text { Score }\end{array}$ & $\frac{\text { Parent }}{\text { District }}$ & $\begin{array}{l}\text { Nominated } \\
\text { Village }\end{array}$ & $\begin{array}{l}\text { Total } \\
\text { Score }\end{array}$ \\
\hline 1 & & $\begin{array}{c}\text { Mandiangin } \\
\text { Tuo }\end{array}$ & 874 & & Guruh Baru & 954 & & $\begin{array}{l}\text { Sungai } \\
\text { Rotan }\end{array}$ & 911 \\
\hline 2 & & Rangkiling & 861 & & $\begin{array}{l}\text { Sungai } \\
\text { Butang }\end{array}$ & 1019 & & $\begin{array}{c}\text { Bukit } \\
\text { Peranginan }\end{array}$ & 1019 \\
\hline 3 & & $\begin{array}{l}\text { Rangkiling } \\
\text { Simpang }\end{array}$ & 913 & & Butang Baru & 1047 & & $\begin{array}{l}\text { Muaro } \\
\text { Ketalo }\end{array}$ & 969 \\
\hline 4 & & Gurun Tuo & 878 & & Suka Maju & 1012 & & $\begin{array}{l}\text { Simpang } \\
\text { Kertopati }\end{array}$ & 878 \\
\hline 5 & & $\begin{array}{l}\text { Gurun Tuo } \\
\text { Simpang }\end{array}$ & 913 & & $\begin{array}{l}\text { Jati Baru } \\
\text { Mudo }\end{array}$ & 979 & & Kertopati & 861 \\
\hline 6 & & Pemusiran & 982 & & Jati Baru & 997 & & $\begin{array}{l}\text { Talang } \\
\text { Serdang }\end{array}$ & 959 \\
\hline 7 & & Gurun Mudo & 887 & & Meranti Baru & 1023 & & $\begin{array}{l}\text { Taman } \\
\text { Dewa }\end{array}$ & 999 \\
\hline 8 & & Gurun Baru & 854 & & Meranti Raya & 1000 & & Kute Jaye & 894 \\
\hline 9 & & & & & Jernang Baru & 976 & & $\begin{array}{l}\text { Mandiangin } \\
\text { Pasar }\end{array}$ & 1063 \\
\hline 10 & & & & & $\begin{array}{l}\text { Petiduran } \\
\text { Baru }\end{array}$ & 970 & & Mandiangin & 958 \\
\hline \multicolumn{3}{|c|}{ TOTAL } & 7,162 & & & 9,977 & & & 9,511 \\
\hline \multicolumn{3}{|c|}{ AVERAGE } & 895 & & & 998 & & & 951 \\
\hline \multicolumn{3}{|c|}{$\begin{array}{l}\text { TOTAL MINIMUM } \\
\text { SCORE }\end{array}$} & 854 & & & 954 & & & 861 \\
\hline \multicolumn{3}{|c|}{$\begin{array}{l}\text { TOTAL MAXIMUM } \\
\text { SCORE }\end{array}$} & 982 & & & 1047 & & & 1063 \\
\hline
\end{tabular}

Source: Data Processing, 2017.

Table 18. Mapping of villages in Mandiangin district.

\begin{tabular}{ccccc}
\hline \multirow{2}{*}{ Mapping } & \multicolumn{3}{c}{ Score Average } & \multirow{2}{*}{ Difference } \\
\cline { 2 - 4 } & $\begin{array}{c}\text { Parent } \\
\text { District }\end{array}$ & $\begin{array}{c}\text { Formed } \\
\text { District 1 }\end{array}$ & $\begin{array}{c}\text { Formed } \\
\text { District 2 }\end{array}$ & \\
\hline Alternative 1 & 926 & 998 & & -71 \\
Alternative 2 & 902 & 950 & 998 & -48 \\
& & & & -95 \\
Alternative 3 & 951 & 895 & 998 & 56 \\
& & & & -47
\end{tabular}

Source: Data Processing, 2017.

means that proposed parent district has lower potential than proposed formed district 1 , and proposed parent district has higher potential than proposed formed district 2. In alternative 3, comparison between proposed parent district and proposed formed district 56 is by -47 , which means that proposed parent district has higher potential than proposed formed district 1, and proposed parent district has higher potential than proposed formed district 2 . 
Therefore, it is clear that alternative 3 is decided to be choice 1 . This is based on consideration that formation according to division of governmental working area is relatively more balanced in terms of potential than formation by alternative 1 and alternative 2 regarding the 19 variables. Differences between parent district and proposed parent district and proposed formed district in alternative 3 are 56 and -47 , while average distance in alternative 1 is -71 and in alternative 2 is -48 and -95 . Therefore, it can be concluded that regional reordering by formation of Mandiangin District can be designed in 3 (three) best alternatives of regional reordering as follows:

Regional reordering by formation of Mandiangin District can be designed in 3 (three) best alternatives of regional reordering as follows:

1) Alternative 1 (score difference -71)

- Proposed parent district with average score of 926 consisting of 18 villages, namely Mandiangin Tuo, Mandiangin, Taman Dewa, Simpang Kertopati, Rangkiling, Rangkiling Simpang, Gurun Tuo, Gurun Tuo Simpang, Kertopati, Pemusiran, Gurun Mudo, Bukit Peranginan, Muaro Ketalo, Talang Serdang, Mandiangin Pasar, Kute Jaye, Sungai Rotan and Gurun Baru.

* The proposed formed district with average score of 998 consisting of 10 villages, namely Guruh Baru, Sungai Butang, Butang Baru, Suka Maju, Jati Baru Mudo, Jati Baru, Meranti Baru, Meranti Raya, Jernang Baru and Petiduran Baru.

2) Alternative 2 (score differences $\mathbf{- 4 8}$ and -95 )

* Proposed parent district with average score of 902 consisting of 9 villages, namely Mandiangin, Mandiangin Tuo, Rangkiling, Rangkiling Simpang, Gurun Tuo, Gurun Tuo Simpang, Pemusiran, Gurun Mudo and Gurun Baru.

* The proposed formed district 1 with average score of 950 consisting of 9 villages, namely Sungai Rotan, Bukit Peranginan, Muaro Ketalo, Simpang Kertopati, Kertopati, Talang Serdang, Taman Dewa, Kute Jaye and Mandiangin Pasar.

* And the proposed formed district 2 with average score of 998 consisting of 10 villages, namely Guruh Baru, Sungai Butang, Butang Baru, Suka Maju, Jati Baru Mudo, Jati Baru, Meranti Baru, Meranti Raya, Jernang Baru and Petiduran Baru.

\section{3) Alternative 3 (score differences 56 and -47)}

* The proposed parent district with average score of 951 consisting of 10 villages, namely Sungai Rotan, Bukit Peranginan, Muaro Ketalo, Simpang Kertopati, Kertopati, Talang Serdang, Taman Dewa, Kute Jaye and Mandiangin Pasar.

* The proposed formed district 1 with average score of 895 consisting of 8 villages, namely Mandiangin Tuo, Rangkiling, Rangkiling Simpang, Gurun Tuo, Gurun Tuo Simpang, Pemusiran, Gurun Mudo and Gurun Baru.

* And the proposed formed district 2 with average score of 998 consisting of 10 villages, namely Guruh Baru, Sungai Butang, Butang Baru, Suka Maju, Jati 
Baru Mudo, Jati Baru, Meranti Baru, Meranti Raya, Jernang Baru and Petiduran Baru.

a) Formation of Batang Asai District and Mandiangin District based on Aspect of Public Aspiration and Availability of Public Services

From the aspect of public aspiration, in both districts in Sarolangun Regency, namely Batang Asai District and Mandiangin District, in principle, a majority of community, public figures, religious leaders, youth figures, female leaders and educational figures, are agreed on the formation of district. One of the importances of public aspiration in supporting the formation of district is the inclusion of public aspiration in determining the district capital in case formation of district is implemented.

Planned capital for newly formed Batang Asai district is Batin Pengambang village or Muara Air Dua village for alternative 1 and alternative 2, and planned capitals for 2 newly formed districts for alternative 3 are Sungai Baung village and Muara Air Dua village. Planned capital for newly formed Mandiangin District for alternative 1 is Butang Baru village or Meranti Baru village, for alternative 2 are Simpang Kertopati village and Butang Baru village, and for alternative 3 are Rangkiling Simpang village and Butang Baru village.

From the aspects of public services and quality of public services in the area of education, health, public facilities, licensing and public participation, it is shown that public services provided in almost all districts is much more poorly than at the level of regency and village/sub-district.

b) Formation of Batang Asai District and Mandiangin District based on Regional Condition

A region is categorized as underdeveloped due to several factors such as:

1) Geography Geographically in general, underdeveloped region is relatively difficult to access since the location is in hinterland, mountains, islands, coastal area, and remote island or due to other geomorphological factors making it difficult to access by transportation and communication media.

2) Natural Resources. Some underdeveloped regions don't have natural resources, or they have great natural resources but situated in area that is preserved or unable to exploit, or they are underdeveloped due to over-exploitation of natural resources.

3) Human Resources. In general, people living in underdeveloped regions have relatively low level of education, knowledge and skills and underdeveloped customary institution.

4) Facilities and Infrastructures Limited availability of facilities and Infrastructures of communication, transportation, clean water, irrigation, health, education, and other services has made community in underdeveloped region difficult to do economic and social activities.

5) Disaster-Prone and Social Conflict Area A region that frequently suffer from natural disaster such as earthquake, water shortage and flood, and social conflict is more likely to experience disturbance in activities of social and eco- 
nomic development.

6) Developmental Policy A region may be underdeveloped due to poor policies, such as paying less attention to development of the underdeveloped areas, unsuitable approach and priority of development, and not involving the customary institution in planning and development.

Distribution of underdeveloped regions is geographically classified into several groups:

1) Regions located in hinterland areas, the edge or middle of forest, and mountains that generally have no or little access to other relatively more developed regions.

2) Regions located in small islands, group of islands that are populated and have difficult access to other more developed regions.

3) Regions that are in part or in whole located administratively at the borderland, either maritime or land borders.

4) Regions located in areas that are more likely suffer from natural disasters, such as earthquake, landslide, eruption, or flood.

5) Regions that most of its areas are coastal.

Based on result of analysis and direct observation by District Formation Team, it is found that both districts, Batang Asai District and Mandiangin District, have different regional condition, in which Batang Asai District is categorized as underdeveloped region (underdeveloped district), contrast with Mandiangin District which is categorized as fairly proper and developable without needing any specific intervention from government.

\section{Conclusion}

To ensure the successful implementation of regional reordering and development, it is necessary to consider capability of government, from the lowest to the highest level, in implementation of public services, governance and development effectively and efficiently, and it is recommended as follows:

1) Providing that there are three alternatives presented, it is expected to have continuous development model.

2) As district is local agency of regency/city government, it is necessary to have system of delegation of authority from Regent to Camat in Sarolangun Regency due to geographically difficult area.

3) Making organizational design of district according to potential and characteristic of districts (typology of district) along with model and nature of authority delegated by Regent to Camat;

4) Making performance and logistic budgeting for district according to significance of the variable of authority of Camat, potential and solution of each district;

5) Making design of measurement and evaluation of performance for district according to authority of Camat, potential and solution of each district;

6) All equipment, personnel and expenses needed for implementation of re- 
gional reordering are under responsibility of Local Government, including improvement of all citizenship administration services for regions related to formation of district, including Identity Card (KTP), Family Register (KK), and other citizenship administration.

\section{References}

[1] Kolopaking, L.M., et al. (2008) District for People's Welfare. Center for Agricultural and Rural Development Studies-Bogor Agricultural University, Bogor.

[2] Affairs, Ministry of Home. Law No. 32 of 2004 on Local Government and Government Regulations No. 19 of 2008 on Formation of Autonomous Region. 32 and 19 Indonesia, 2004 and 2008. Regulation.

[3] Law No. 23 of 2014 on Local Government. 23 Indonesia, 2014. Regulations.

[4] Simangunsong, F. (2014) Development of Subdistrict Organizations Post-Birth of Law Number 23 Year 2014 about Local Government. Lecture Papers for Graduate School, Master's and Doctorate, Institute of Domestic Government, Bandung. (No Published)

[5] Manan, B. (2001) Facing the Down of Regional Autonomy. The Center pf Law Studies Faculty of Law UII, Yogyakarta, p. 147.

[6] Wasistiono, S., et al. (2003) Selected Topics on Local Government. Revision Editor, Fokusmedia, Bandung.

[7] (2004) Modul for Optimization of Role and Function of District in Improving Public Services, Upgrading Material for Camats in Indonesia. Badan Diklat, Jakarta.

[8] (2002) Reorganization of District Institution. Fokusmedia, Bandung.

[9] Syaukani, G. and Rasyid. (2002) Regional Autonomy within the Unitary State. Pustaka Pelajar, Yogyakarta. 